\title{
Subliminal Bir Güç Göstergesi: Yabancı Dil Olarak Türkçe Öğretiminde Ders Kitapları*
}

\author{
ÖĞR. GÖR. DR. RAMAZAN ŞİMŞEK** - PROF. DR. ILLHAN ERDEM ${ }^{* * *}$
}

$\ddot{O} z$

İçinde bulunduğumuz yüzyılda kullanılan iletişim araçlarından, eğitim materyallerine kadar her kaynakta alıcıya yönlendirilen örtük ya da açı mesajlar bulunmaktadır. Yazılı ya da sözlü metinlerin ana gövdesini oluşturan bu mesajlar eğitim sürecinde de çeşitli materyaller aracilığıyla kendine oldukça geniş yer bulmaktadır. Bu kapsamda özellikle son 10 yılda kayda değer bir ivme kazanan Türkçenin yabancı dil olarak öğretimi süreci ile birlikte çeşitli ders materyalleri geliştirilmiştir. Bu çalışma ders kitaplarının sadece mekanik gramer bilgisiyle donatılmış aktörler olmadığı gözetilerek yürütülmüştür. Ders kitaplarında kullanılan metinler sayısallaştırılmış, bilgisayar yazılımı ile analiz edilmiş, her ünitede öne çıkan ilk 3 içerik kelimesinin eşdizimlilik analizi yapılmıştır. Bu aşamanın ardından Fairclough'nun (2001) eleştirel söylem analizi yöntemi ile ders kitaplarında yer alan metinler analiz edilmiştir. Nye'nn (2005) "Yumuşak Güç" teorisi etrafında Türkçe öğrenen yabancların davranış ve tutumlarının şekillendirilmeye çalışıldığı; Batı medeniyetiyle müsemma olan kapitalizm, tüketim kültürü, popüler kültür, modernite kavramlarının ders kitabı söyleminde örtük olarak eleştirildiği tespit edilmiştir

Anahtar sözcükler: Ders kitabı, Söylem, Eleştirel Söylem Analizi, Batı

\section{A SUBLIMINAL POWER INDICATOR: COURSE BOOKS IN TURKISH TEACHING} AS A FOREIGN LANGUAGE

\section{Abstract}

All There are implicit or explicit messages directed to the receivers in every resource, from the communication tools used in the the last century to educational materials. These messages, which constitute the main body of written or spoken texts, find themselves quite wide in the education process through various materials. In this context, especially with the process of teaching Turkish as a foreign language, which has gained considerable momentum in the last 10 years, various course materials have been developed. This study was carried out considering that the textbooks are not only actors equipped with mechanical grammar knowledge. The texts used in the textbooks are digitized, analyzed with computer software, and collocation analysis of the first 3 content words that stand out in each unit is made. After this stage, the texts in the textbooks

\footnotetext{
* Bu Çalışma, Subliminal Bir Güç Göstergesi: Yabancı Dil Olarak Türkçe Öğretiminde Ders Kitapları isimli doktora tezinden üretilmiştir.

** Nevşehir Hacı Bektaş Veli Üniversitesi, ramazansimsek@nevehir.edu.tr, orcid.org/0000-0002-8295-8903

*** İnönü Üniversitesi, ilhan.erdem@inonu.edu.tr, orcid.org/0000-0002-4244-6225 
were analyzed by Fairclough's (2001) critical discourse analysis method. It has been determined that as part of Nye's (2005) theory of "Soft Power", the books attempt to shape the behaviors and attitudes of foreigners learning Turkish, and the concepts of capitalism, consumer culture, popular culture and modernity belonging to Western civilization are implicitly criticized in the textbook discourse.

Keywords: Textbook, Discourse, Critical Discourse Analysis, Western Civilization

\section{GİRIŞ}

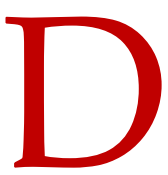

il, insanlar tarafından kullanılan, sınırlı miktarda seslerle, sınırsız sayıda cümleler üretmeye imkân sağlayan bir düzenektir (Ungan, 2013). İnsanların duygu ve düşüncelerini ifade etmelerini sağlayarak toplumların oluşması ve medeniyet kurmasında önemli bir rol üstlenen dil (Banguoğlu, 2015: 10) temel iletişim aracı olarak öne çıkmaktadır.

Bir toplumu gelişigüzel bir insan yığını olmaktan çıkarıp uluslaşmasını sağlayan ana dili (Özdemir, 1983: 21), “İnsanın doğup büyüdüğü aile ve soyca bağlı bulunduğu toplum çevresinden öğrendiği, bilinçaltına inen ve kişilerle toplum arasındaki ilişkilerde en güçlü bağı oluşturan dil” (Korkmaz, 1992: 8) iletişim ve bildirişim sürecine devingen bir özellik kazandırmaktadır.

Bireyin çevresiyle sağlıklı bir iletişim kurmasında şüphesiz ana dilini doğru, güzel ve etkili kullanması önemli bir durumdur. Bununla birlikte bireyler ve toplumlar arası ilişkilerin yoğunlaştı̆̆ı, teknolojinin hızla yayıldığı bu çağda, insanların ortak bir paydada buluşma isteği yabancı bir dili ya da dilleri öğrenme ihtiyacını ortaya çıkarmıştır. Bu bağlamda küreselleşen ve küçük bir şehir haline gelen günümüz dünyasının gelişimine paralel olarak yabancı dil öğrenme ihtiyacının da arttı̆̆ söylenebilir.

Yabancı dil, "belirli bir ülkedeki veya bölgedeki halkın büyük bölümünün ana dili olmayan, okullarda eğitim aracı olarak kullanılmayan ve yönetimde, medyada iletişim işleri ile geniş bir biçimde yer almayan dildir" (Richards vd 2002: 206; Akt. Durmuş, 2013: 16). Barın (1992, s.6), yabancı dil öğrenme sebeplerini "iyi bir eğitim almak, dil politikasındaki evrensellik, değişik kültürleri tanımak, göçler, ticaret, turizm” başlıkları altında toplamıştır. Yabancı dil öğrenmenin avantajları genel olarak kültürel ve entelektüel birikim, ekonomi ve iletişim olarak ifade edilebilir.

Yabancı dil olarak Türkçe öğretimi (YDTÖ) 11. asra kadar uzanmakta olup (Erdem, 2009) resmi belgeler ışı̆̆ında bu süreç Kaşgarlı Mahmut'un Divanü Lugati't-Türk isimli eseriyle başladığı kabul edilmektedir. 20. Yüzyılın son çeyreği itibarı ile ivmelenen bu süreç 21. yüzyılın başlarında Ortadoğu'daki demografik hareketler ve göç dalgaları ile zirveyi görmüştür. Bu ivme ile birlikte Türkçenin yabancı dil olarak öğretimi için geliştirilen materyallerin sayısı da önemli oranda artmıştır.

Türkiye'nin üzerinde bulunduğu coğrafya siyasal ve toplumsal anlamda aktif dinamikleri bünyesinde barındırmaktadır. Bu dinamiklerle beraber içinde bulunduğumuz coğrafyada demografik ve sosyopolitik fay hatlarındaki hareketlenmeler ülkemize gelen yabancı sayısını ciddi miktarlarda artırmıştır. Ayrıca Şekil 1'de de görüldüğü üzere Yurtdışı Türkler ve Akraba 
Topluluklar Başkanlığı ve bireysel başvurular aracılığıyla son yıllarda ülkemizde yükseköğretim kurumlarına kayıt yaptıran öğrenci sayısında ciddi artış vardır.

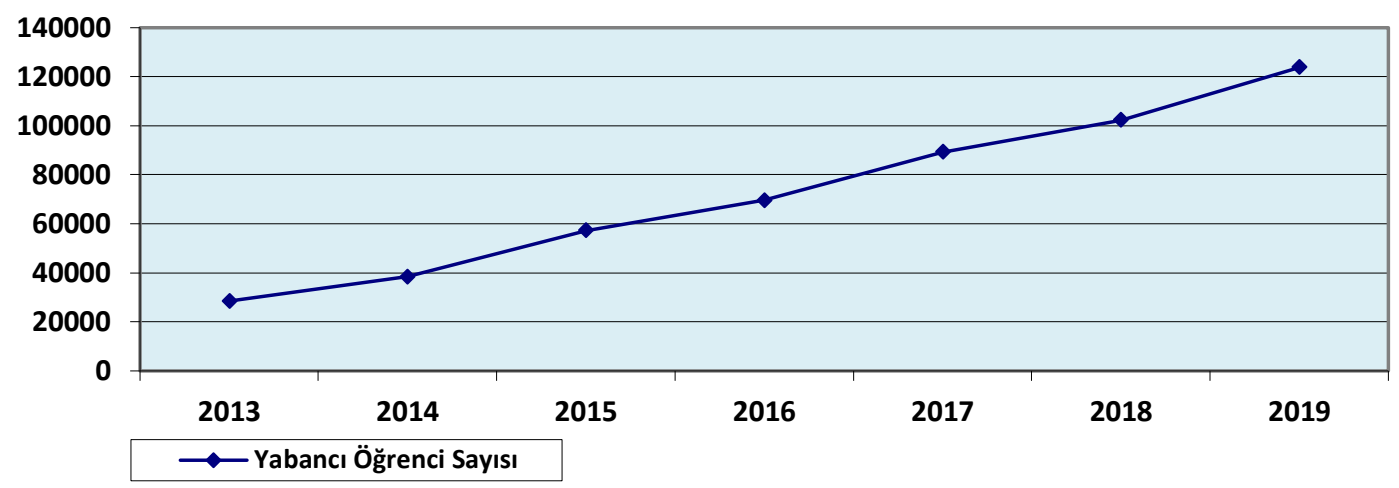

Şekil 1: Yıllara Göre Türkiye’deki Üniversitelere Kayıt Yaptıran Yabancı Öğrenci Sayısı Kaynak: https://istatistik.yok.gov.tr/

Tüm bu faktörlerin bileşkesi olarak hitap edilen kitlenin milyonları aşmasıyla eğitim, öğrenim, adaptasyon ihtiyacı açığa çıkmış; yabancı dil olarak Türkçe öğretimi sürecin lokomotifi haline gelmiştir. Bu bağlamda açığa çıkan ihtiyacı giderme maksadıyla üniversiteler bünyesinde hizmet veren Türkçe Öğretim Merkezleri (TÖMER) kurulmuştur. Bu kurumlarda dört temel dil becerisi ile birlikte gramer bilgisi Yabancı dil olarak Türkçe öğretimi sürecinin ana bileşenlerini oluşturmaktadır. Her TÖMER süreç içinde bir ders kitabı ve ders kitabı muhtevasında yer alan bir öğretim programı kullanmaktadır. Bu çalışmada da Türkçenin yabancı dil olarak öğretiminde kullanılan ders kitapları incelenecektir.

\subsection{Söylem}

Söylem kavramı tarihsel süreç içinde genellikle sosyoloji alanı ile ilişkilendirilmiş olup içinde bulunduğumuz yüzyılda ise disiplinler arası bir araştırma alanı olarak öne çıkmaktadır.

Söylem, Latince "discurrere" (oraya buraya koşuşturma, gidiş gelişler) kelimesinden ve:/veya "uzaklaşma", "eritme", "yayılma" ile "discursus" kelimesinin muhtelif versiyonlarına karşıllk gelir; mecazî anlamında da "özne hakkında uzun uzadıya konuşma", "bir şey hakkında iletişim" anlamına gelir (Sözen, 1999: 9). Günay’a (2018) göre söylem; "uzamsal, zamansal ve kişiye bağlı değişkenler açısından oluşturulmuş dil yapılarıdır.” Parker ise (1992) söylemi; “birbirleri ile ilişkili metinlerden oluşan, onların üretimi, anlamlandırılması ve yayılması ile bir nesne haline gelen dilsel yapı" olarak tanımlamıştır. Maingueneau'ya göre söylem; "tümcelerden oluşan değil, tümcelerle oluşan ya da tümcelerle gerçekleşen bir dilsel yapı" (akt. Günay, 2018: 22) şeklinde tanımlamıştır.

Sosyal bir kurum olarak kabul gören dilin bireysel kullanımı, düşünme, değerlendirme, yorumlama, eylem ve etkileşimlerin uygun zamanda, uygun bağlamda ve uygun araçlarla ifade edilmesi ile söylem oluşturulur. Birey, söylemleriyle kendini; bir sosyal gruba ya da ağa üyelik, ilgililik, yakınlık ya da karşıtlık gibi şekillerde konumlandırır (Gee 2005: 32-33). Söylemin en küçük birimi -üzerinde tartışmalar olsa da- cümledir. Cümle, dilbilgisi bakımından tamamlanmış ve bir düşünce ya da oluşu tam olarak ifade eden dilbirimi ya da anlatımdır (Gee, 2005) 
Söylem kelimesi alan yazın ve günlük hayatta çok farklı anlamlarda kullanılmaktadır. Bunlardan başlıcaları; görüş ve bakış açısı, anlatım şekli, kişi ya da topluluğa ait karakteristik özellik taşıyan öğretiler, ideoloji, sözlü ya da yazılı metinler, biçem, dil, sav ve görüşler olarak sayılabilir (Kocaman, 2009: 5). Genellikle tematik bir yapı etrafinda oluşan söylem cümlelerin içerdiği anlam yelpazesinden daha geniş ve derin mefhumları bünyesinde bulundurmaktadır. Bu yönü ile "söylem" derin yapıdan aşkın, cümleler ötesi bir yapıyı içermektedir. Söylem, en kapsayıcı tanımı ile yazılı, sözlü, görsel anlam yüklerinin bir araya gelmesiyle meydana gelen ifadeler bütünü olarak tanımlanabilir. Bu süreçte ilgili göstergelere dil kullanıcısının yüklediği özgün ya da derin anlam katmanları söylemin temel yapı taşını oluşturmakta olup bu içeriği irdeleyen araştırmacılara göre farklı yorumlanabilmektedir. Bu yorumlama faaliyeti akademik literatürde "Söylem Analizi" olarak tanımlanmaktadır.

\subsection{Söylem Analizi ve Eleştirel Söylem Analizi (ESA)}

Söylem analizi, genellikle konuşmalar ve metinler üzerinden gerçekleştirilen bir çözümleme tekniğidir (Arkonaç, 2012: 105). Bu teknik, analiz sürecinde söylemi merkeze alarak gündelik konuşmaları ve metinleri de kendi bağlamları içinde inceleme esasına dayanır (Baş vd, 2008: 24). Söylem analizi; "metinler aracılığıyla oluşan anlam ürünleri ile ilgilenen geniş kapsamlı sosyal ve kültürel araştırmalar içinde kullanılan bir araştırma yöntemidir." (Çelik vd 2008: 99). Söylemi temel alan bu çözümleme yapısalcılık, postyapısalcılık, postmodernizm, hermenötik vb. akımlardan beslenir (Sözen, 1999).

20. yüzyılın son çeyreğinde Eleştirel Söylem Analizi (ESA), diğer formlardaki söylem çalışmalarından farklı yaklaşımlarla Avrupa'da ortaya çıkmıştır. Geçmişi, Habermars'ın öncülük ettiği Frankfurt Okulu'nun Eleştirel Teorisi'ne ve Foucault'nun söylem için geliştirdiği postmodern yaklaşıma kadar gider. Habermas "dilin, aynı zamanda baskının ve toplumsal gücün vasıtası olduğunu" iddia etmiştir.

Michael Foucault'nun söyleme yaklaşımı ESA analistleri için yeni bir başlangıç noktası olmuştur. Foucault'ya (2003) göre söylem, güç ile ilişkilidir. Bireyin ya da söylem içeriğinin çıkış noktası içinde bulunduğu duruma, tabii olduğu otoriteye göre söylemi şekillendirmektedir. Söylem, ast-üst ilişkisi yani hiyerarşi, eleştiride bulunma ya da destek verme gibi durumlardan etkilenmektedir.

ESA'nın ayırt edici özelliği Fairclough'un söylem algısında yatmaktadır ve onun analizi "toplumsal pratik biçimi olarak görülen dil kullanımı ve Söylem Analizi, metinlerin sosyokültürel pratikte nasıl işlendiğinin analizi," (Fairclough, 1995: 7) şeklinde ifade edilebilir. Fairclough çalışmalarının çoğunda dil ve toplumsal yapılar arasındaki ilişkiye ve dilde gizli olan toplumsal ve politik mesajların nasıl açığa çıkartılacağına dikkat çekmiştir. ESA alanındaki diğer meşhur akademisyenler, söylemi farklı ideolojilerin, eşitsizliklerin ve güç istismarının bir yansıması olarak görmüşlerdir. Örneğin, Van Dijk ESA tanımında şunu vurgular: Eleştirel Söylem Analizi, öncelikle toplumsal güç istismarının, hâkimiyetin ve eşitsizliğin; toplumsal ve politik bağlamda metinler ve konuşmalar ile ortaya çıkmasının, yeniden üretilmesinin ve karşı konulmasının yolunu inceleyen analiz tabanlı bir araştırmadır. ESA'nın amacı; hâkimiyet, ayrımcılık, güç ve kontrol arasındaki gizli ve şeffaf yapısal ilişkileri analiz etmek olarak tanımlanmaktadır (Wodak, 1995). Tüm 
tanımlarda olduğu gibi ESA'nın amacı sadece metinlerde kullanılan dili analiz etmek değil aynı zamanda toplumsal pratikler ile bağlantılar da oluşturmaktır.

"Eleştirel söylemin, a) dil ve toplum arasındaki ilişkiye ve b) analiz ile analiz edilen uygulamalar arasındaki ilişkiye bakış açısıyla diğerlerinden ayrıştığı" iddia edilmektedir (Wodak, 1997: 173). Kress ve Hodge (1979), aralarındaki güçlü ve etkili bağlantılar nedeniyle dilbilimsel yapı ile toplumsal yapının birbirinden ayrılamayacağı fikrini desteklemektedir. Söylemin toplumsal anlamlar olmadan var olamayacağını da iddia edilmektedir. ESA hakkındaki tüm bu bakış açıları ESA'nın disiplinler arası birçok hedefe sahip geniş bir alan olduğunu ileri sürmektedir. Neticede, ESA'nın temel ilkeleri Wodak ve Fairclough (1997: 271-280) tarafından şöyle özetlenmiştir:

1- ESA toplumsal sorunları ele alır

2- Güç ilişkileri söylemseldir.

3- Söylem, toplumu ve kültürü oluşturur.

4- Söylemin ideolojik bir işlevi vardır.

5- Söylem tarihseldir

6- Metin ve toplum arasındaki bağa aracilık eder.

7- Söylem analizi yorumlayııı ve açılayıcıdır.

8- Söylem, bir toplumsal eylem şeklidir (Van Dijk, 1998: 53)

Eleştirel Söylem Analizi (ESA) bu ilkelere çerçevesinde araştırmalarda disiplinler arası bir yörünge ile hareket etmektedir. Toplum ve dil ilişkisi; metin, söylem ve toplum ilişkisi; iktidar(güç) ve söylem ilişkisi ESA'nın temel araştırma alanları olarak öne çıktığı söylenebilir. Zira Eleştirel Söylem Analizi, araştırma sürecinde elde edilen veri setinin sistemli ve ayrıntılı bir şekilde tetkik edilmesini esas alır (Baş ve Akturan, 2008: 24). Anlatıların anlamlarını, onları "yer, zaman ve bağlama oturtmadan" ortaya çıkarmaya çalışmak yanlış sonuçlara kapı aralar. Punch (2014: 214), Van Dijk (2011: 31) ve Sözen (1999: 13) de aynı alana değinerek belgelerde kullanılan dilin, sosyal ve politik bağlamla olan ilişkisine ve metin bütünlüğüne dikkat çekerler. Ancak burada temel amaç hiçbir zaman mutlak gerçeğe ulaşmak değildir. Zira söylem analizinin temelini "değişkenlik", "hermenötik" oluşturmaktadır. Dolayısıyla verilerden elde edilen çıtılar görecelidir. Onu sistematik bir şekilde değişken kılan parametre ise bağlamın kendisidir (Baş vd, 2008: 26). Çünkü çözümleme sürecinde amaç metnin yüzey yapısında yer alan unsurlardan ziyade derin yapıdaki gönderimleri ortaya çıkarmaktır. Bir başka ifade ile "söylem analizi satır aralarını okuma sanatıdır." (Baş vd. 2008: 29). Söylem analizinde gaye, ifadelere bir anlam üretmektir (Nixon vd. 2007: 75). Metinlerde ortaya çıkan sorulara kesin cevaplar vermek yerine onları var eden bağlamla birlikte düşünsel bir aktivite gerçekleştirmektir (Güllüoğlu, 2012: 232-233).

\subsection{Söylem ve İdeoloji}

İdeoloji, belirli bir grubun, kitlenin ya da toplumun eylemlerinin dayandırıldığ değer, inanç, ilke ve tutum olarak tanımlanabilir. Türk Dil Kurumu'na göre ideoloji siyasal veya toplumsal bir öğreti oluşturan, bir hükûmetin, bir partinin, bir grubun davranışlarına yön veren politik, hukuki, bilimsel, felsefi, dinî, moral, estetik düşünceler bütünü" olarak değerlendirilmektedir (TDK, 2017). Eagleton, ideoloji kelimesini; “farklı kavramsal liflerle bir doku halinde örülmüş bir metin" (2011: 17) olarak tanımlar. 
Düşünce ve ideolojinin bileşkesi olarak değerlendirilebilecek "İdeolojik söylem" mevcut gerçekliğin bir düşünce ekseninde yapılandırılarak dilsel göstergelerle karşı tarafa aktarılmasıdır. Foucault da bu süreci "söylemlerin üretici yapısı vardır, yani söylemler açık şekilde tanımladıkları nesneleri sistematik olarak üreten uygulamalardır" (Foucault, 1972: 74) diyerek açıklamıştır. Günlük dil, resmî dil, yazılı ve sözlü dil söylemin oluşumunda oldukça büyük öneme sahiptir. Bu öneme istinaden söylemin ve ideolojinin ifade aracı olarak dil önemli bir mihenk taşıdır.

Fairclough'a (1992) göre ideolojiler, söylemsel pratiklerin (fiziksel dünya, sosyal ilişkiler, sosyal kimlikler), çeşitli anlam boyutlarının içine inşa edilmiş ve hâkimiyet ilişkilerinin üretimine, çoğaltılmasına veya dönüştürülmesine katkıda bulunan gerçekliğin yansımaları olarak anlamlandırılmaktadır. Ayrıca (Fairclough, 1992) ideolojiler; sınıflar, cinsiyetler, kültürel gruplar gibi ögeler üzerinden baskı oluşturulan toplumlarda meydana gelirler. Bu kapsamda Fairclough (1992) ideolojileri makro düzeyde tespit etmenin en iyi yolunun, ideolojilerin yeniden üretildiği, dağıtıldığı, basit günlük konuşmalar/metinler aracılığıyla takviye edildiği mikro seviye söylemleri/etkileşimlerini incelemek olduğunu ileri sürmektedir.

Van Dijk (2000) ideolojilerin fikir sistemleriyle; özellikle de toplumsal gruplar ve hareketler tarafından paylaşılan sosyal, siyasal ya da dini fikirlerle ilişkili olduğunu ifade etmektedir. Van Dijk ideolojinin dil kullanımıyla nasıl ilişkili olduğunu şöyle açıklamıştır: “İdeolojilerden etkilenen en hayati toplumsal pratiklerden biri dil kullanımı ve söylemdir, ki bunlar ideolojileri nasıl edindiğimizi, öğrendiğimizi ya da değiştirdiğimizi de etkiler. Bizim söylemlerimizin çoğu, özellikle de bir grubun üyesi olarak konuştuğumuzda ideoloji temelli fikirler içerir" (Van Dijk, 2000). Van Dijk (2000), ideolojileri tanımlamadaki ilk adımın; ideolojilerin bir grubun kimliği, toplumdaki konumu, diğer gruplarla ilişkileri gibi özelliklerine dayanan sosyal inançlarımızdan oluştuğunu bilmek olduğunu ifade etmiştir.

İdeolojiye sosyo-bilişsel açıdan yaklaşan Van Dijk toplum içinde yer alan sosyal grupların fikir sistemleri ideolojiyi ilişkilendirmektedir. Bu bağlamda dil kullanımı ve ideoloji doğrudan ilişkilendirilmiştir. Hatta bireylerin grup içinde kullandıkları dilin doğrudan ideolojik bir yansıma olarak değerlendirilebileceğini ifade etmiştir.

İdeolojilerin toplumdaki insanlara metinler aracılığıyla doğrudan ve dolaylı olarak aktarıldığı düşünüldüğünde, eleştirel söylem analistleri bunları ortaya çıkarmanın farklı yollarını oluşturmuşlardır.

\subsection{Güç}

Kavramsal olarak birçok tanıma sahip olan güç kavramı genellikle uluslararası ilişkiler ve siyaset bilimi uzmanları arasında tartışılmakta, belirli yönleri öne çıkarılmaktadır. Nye'a (2004:2) göre güç, başkalarının davranışlarını, istediğimiz sonuç doğrultusunda etkileyebilme kapasitesidir. Morgenthau (1985), gücü; hem bir ilişki türü, hem uluslararası politikanın en temel amacı hem de amacın gerçekleştirilmesi için bir araç olarak tanımlamış; Holsti (1964) ise bir ülkenin sahip olduğu imkân ve hareket kabiliyetini ödül, ceza, ikna ve zorlama gibi yöntemler kullanarak karşı tarafın davranışlarını kendi çıkarları doğrultusunda değiştirebilmesi olarak kullanmıştır.

Yapılan tanımlar ve değerlendirmeler kapsamında çok boyutlu karmaşık içerikleri 
bünyesinde barındıran güç kavramı ekonomi, sanat, eğitim gibi kavramları bünyesinde bulundurmakta ve farklı başlıklar altına incelenmektedir. Nye (2005) çalışmasında sert güç ve yumuşak güç kavramları üzerinde durmaktadır.

Sert güç: Genellikle hedef alınan ülkenin ekonomik ve askeri güç unsurlarını hedef alarak söz konusu ülkeyi zorla ikna etme gibi amaçlar doğrultusunda uygulanır. Joseph Nye, sert gücü betimlerken ağırlık olarak askeri unsurun üzerinde durmuştur ve ekonomik unsura çok değinmemiştir. (Nye, 2005: 54)

Yumuşak Güç: Joseph Nye tarafından 1990 yılında "yumuşak güç" olarak adlandırılan bu kavrama göre; uluslararası sistemin geçirdiği değişim, medya ve iletişim araçlarının etkinliğinin artması uluslararası alanda "sert/kaba güç"ün önemini azaltmıştır. Zorbalık yerine iş birliğini öneren Nye (2017), yumuşak gücü; “Ĕ̆er istediğim şeyi istemeni sağlayabilirsem, o zaman yapmak istediğin şeyi yapmaya seni zorlamama gerek yoktur." diyerek tanımlamıştır. Kalın'a (2012) göre yumuşak gücün kullanımında birçok unsur karşımıza çıkmaktadır. Bunlar asker sayısından yahut ekonomik yaptırım gücünden çok bir ülkenin kültürü, sanatı, sineması, mimarisi, müziği, eğitim sistemi, rekabet ortamı, özgürlükleri, demokrasisi, yaratıcı düşüncesi, insan kalitesi ve sosyal sermayesi, tarihi birikimi, kültürel zenginliği, bilim ve teknoloji altyapısı, inovasyon kapasitesi, diplomatik becerisi ve kendini anlatabilme yeteneğinin toplamıdır. $\mathrm{Bu}$ unsurları bir araya getiren bir ülke, bir cazibe merkezi haline gelir. Takip edilen, konuşulan, "hikâyesine kulak kabartılan" bir ülke haline gelir.

Nye (2008: 97) yumuşak gücü şu unsurlara bağlar:

a.Başkalarına çekici geldiği takdirde kültürü,

b. Yurtiçi ve yurtdışında uyumlu hareket ederek sadık kaldığı siyasi değerleri,

c. Meşru ve ahlaki olarak otoriter görülen diş politikaları (Nye, 2008: 97),

Çok yönlü bu faktörlerin toplamını oluşturan yumuşak güç kavramı eğitim, dil politikalarını ve bu politikaları yöneten kamu kurumlarını da doğrudan ilgilendirmekte olup; "hâkim otorite", "güç" başka bir deyişle devlet kavramının işleyişini açık ve örtük hedeflerini şekillendirmektedir.

20. asrın ortalarına kadar eğitim ve diplomaside lingua franca konumunda olan Fransızca; 20. asrın ortalarından itibaren yerini İngilizceye bırakmıştır. Bu değişim sadece teknik gelişim düzeyi ya da siyasal hegemonya ile alakalı olmayıp eğitim, kültür faaliyetleriyle de doğrudan ilgilidir. Fransa Hükümeti 1883 yılında kurulan “Alliance Française" aracılığıyla ülkenin zedelenen itibarını düzeltmek için hatırı sayılır bir çaba ve bütçe ayırmıştır (Nye, 2017: 144). Bu değerlendirmeler çevresinde kendi ana dilini başka toplumlara resmi mecralar aracılığıyla öğretmeyi planlayan ya da öğreten otoriteler açık ve örtük hedeflerini gerçekleştirmek için eğitim kurumları ve materyallerinden, insan gücünden faydalanarak potansiyel yumuşak gücünü aksiyona dökmektedir. Ayrıca planlanan öğretim programı ile ana dili hedef dil olarak öğretilen ülkenin orta ve uzun vadeli toplumsal, siyasal ve ideolojik hedeflerinin gerçekleştirilmesi mümkün kılınmakta olup sert güç kullanmanın insanî ve malî faturası düşünüldüğünde yumuşak güç kullanımının avantajlı olduğu düşünülmektedir. 


\section{YÖNTEM}

Yabancı dil olarak Türkçe öğretiminde kullanılan C1 düzeyi ders kitaplarının incelendiği bu çalışmada nitel yöntem benimsenmiştir. Nitel araştırmayı, "gözlem, görüşme ve doküman analizi gibi nitel veri toplama tekniklerinin kullanıldığı, algıların ve olayların doğal ortamda gerçekçi ve bütüncül bir biçimde ortaya konmasına yönelik nitel bir sürecin izlendiği araştırma" olarak tanımlamak mümkündür (Yıldırım ve Şimşek, 2008: 39). Çalışmanın verileri “Doküman İncelemesi" yöntemi ile toplanmıştır. Doküman incelemesi, bir araştırma problemi hakkında belirli zaman dilimi içerisinde üretilen dokümanlar ya da ilgili konuda birden fazla kaynak tarafından ve değişik aralıklarla üretilmiş dokümanların geniş bir zaman dilimine dayalı analizini olanaklı kılmaktadır (Yıldırım vd. 2002). Verilerin analizinde ise Eleştirel Söylem Analizi yöntemi benimsenmiştir. Söylem analizi, metni sözdizimsel ve semantik sınırların ötesine giderek bir yapısöküme uğratma ve onu kuran niyetin ne olduğunu anlama çabasıdır (Solak, 2011: 3). Söylem analizi; "metinler aracılığıyla oluşan anlam ürünleri ile ilgilenen geniş kapsamlı sosyal ve kültürel araştırmalar içinde kullanılan bir araştırma yöntemidir." (Çelik vd. 2008: 99).

\section{Fairclough'un Eleştirel Söylem Analizi Metodu}

Ders kitabında yer alan metinlerdeki ideolojik etkilerin tanımlanması, alt metinlerin çözümlenmesi amacıyla, incelenen ünitelerin söylemi, Eleştirel Söylem Çözümlemesi (Fairclough, 2001) yöntemi kullanılmıştır. Eleştirel Söylem Analizi yaklaşımlarının en önemlilerinden biri Fairclough'nun "10 Soru” modelidir.

$\mathrm{Bu}$ çalışmada bizim odaklandığımız alan kelime bilgisi bölümüdür. Çalışmanın amacına uygun olacak şekilde Fairclough'nun analiz çerçevesinde yer alan aşağıdaki sorular ve alt sorular kullanılmıştır:

1. Kelimeler hangi deneyimsel değerlere sahiptir?

a. Hangi sınıflandırma şemalarından yararlanılmıştır?

b. Başka kelime ile ifade etme ya da gereğinden fazla kelime ile ifade etme söz konusu $\mathrm{mu}$ ?

2. Kelimelerin ne gibi anlamsal(açımlayıcı) değerleri vardır?

a. Olumlu ya da olumsuz yönde bir değer değişimi var mı?

b. Sık kullanılan eşdizimlilikler nelerdir?

Bu çalışmada söylem çözümlemesi, içerik analizi ile ortaya konulan yapılandırılmış verilerin derinlemesine anlamlandırılmasında önemli bir rol üstlenmiştir.

\section{Evren ve Örneklem}

Araştırmanın evrenini Maarif Vakfı ve TÖMER kurumları bünyesinde yaygın olarak kullanılan Türkçeye Yolculuk YDTÖ ders kitapları oluşturmaktadır. Evren ise Türkçeye Yolculuk YDTÖ C1 düzeyi ders kitabıdır. Veri setinde ideolojik ve fikirsel anlamda öne çıkan ünite içerikleri eleştirel söylem analiziyle değerlendirilmiştir. Belirtilen kaynaklar edisyonlu olup uzman ekiplerce düzenlenmiştir. C1 düzeyi ders kitaplarının özellikle araştırma kapsamına alınmasında eleştirel söylem analizi için bu ders kitaplarının zengin nitelikte veri barındırdığına yönelik beklentidir. 


\section{Verilerin Analizi}

Araştırma kapsamında incelenen yabancı dil olarak Türkçe öğretiminde kullanılan C1 düzeyi ders kitapları bilgisayar ortamına aktarılmış ve kitaplarda yer alan metinler UTF-8 kod dönüşümünden geçirilip sayısallaştırılarak veri seti oluşturulmuştur. Elde edilen veri seti Wordsmith Tools 7.0 yazılımı ile analize hazır hale getirilmiştir. Her ünitede tema içeriği ile doğrudan ilgili olup frekans değeri en yüksek olan kelimeler ve bu kelimelerin en sık karşılaşılan eşdizimlilikleri Wordsmith Tools 7.0 yazılımı ile tespit edilmiştir.

Wordsmith Tools 7.0 yazılımının kelime sayımı modülü (wordlist) ile ünitelerdeki metinlerin frekans analizi gerçekleştirilmiş ve ünitelerde içerikle ilgili frekans değeri en yüksek olan 3 kelime tespit edilmiştir. Ünitelerdeki en sık üç içerik kelimesinin saptanmasından sonra bu kelimelerin sık karşılaşılan eşdizimlilik temaları Wordsmith Concordance (bağlam analizi) modülü ile analiz edilmiştir. Böylece ünitelerde en sık karşılaşılan 3 kelimenin bağlam(concordance) analizi yapılmıştır. Akabinde ise bu içerik kelimelerinin eşdizimlilik analizi gerçekleştirilmiştir. Ünitelerde en sık karşılaşılan bu kelimelerin eşdizimlilik taraması genellikle +/- 1 açıklıkla yapılmış olsa da bağlama göre +/- 5 açıklığı da kullanılmıştır. Öne çıkan içerik kelimelerinin eşdizimlilik ve bağlam analizi üzerinden eleştirel söylem analizi gerçekleştirilmiştir.

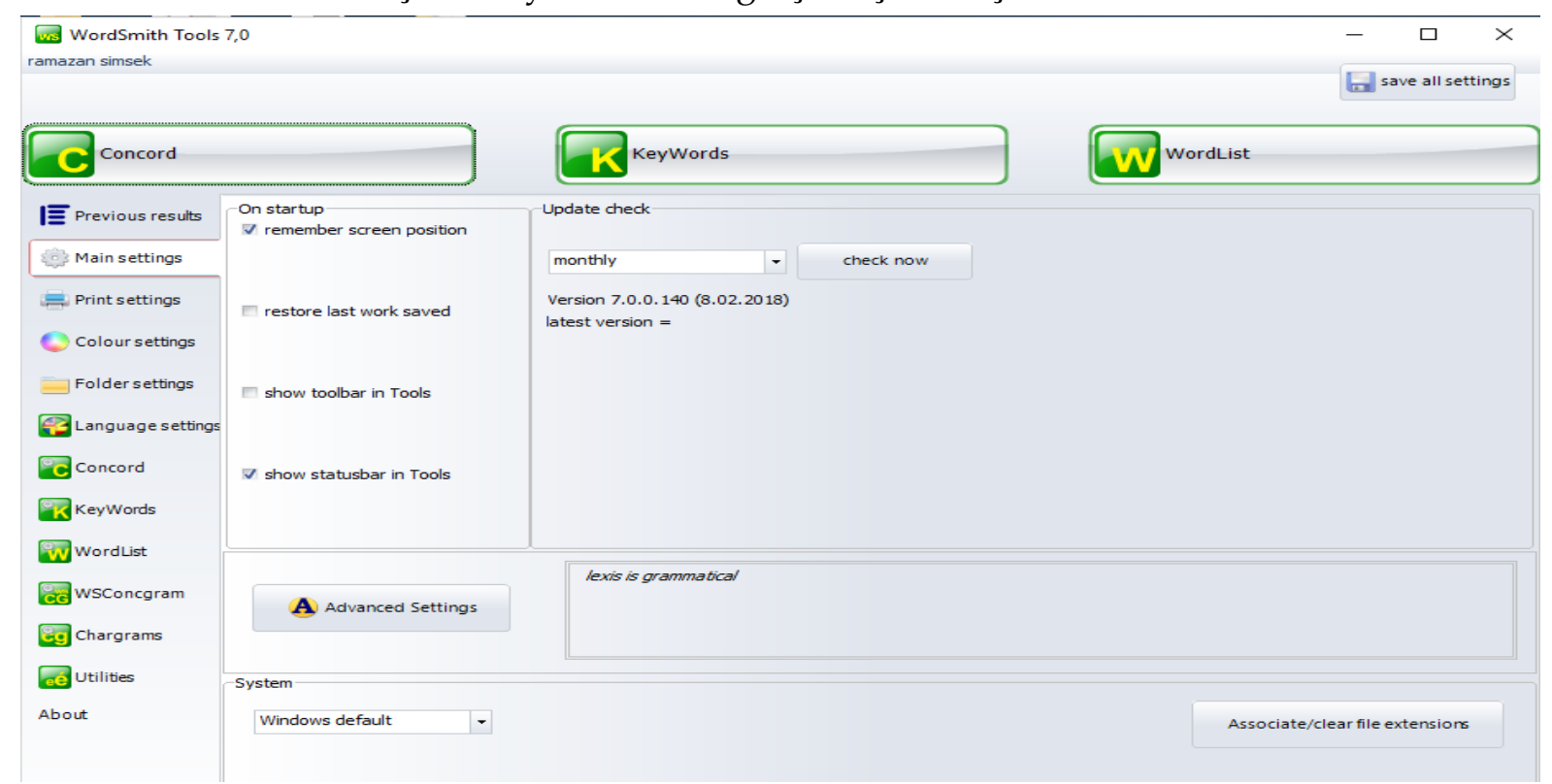

Şekil 2.. WordSmith Tools Programının Arayüzü

\section{BULGULAR}

\subsection{Türkçeye Yolculuk C1 Düzeyi Yabancılar Dil Olarak Türkçe Öğretimi Ders Kitabında Öne Çıkan Kavramlar ve Eşdizimlilikleri}

$\mathrm{Bu}$ bölümde ünitelerde yer alan metinlerin öne çıkan kavramları ve içerik kelimelerinin analizi yapılmıştır. Türkçeye Yolculuk C1 düzeyi yabancılar dil olarak Türkçe öğretimi ders kitabında incelenen ilk bölüm1.ünite olup, ünitenin öne çıkan kelimeleri ve frekans değerleri tablolarla gösterilmiştir. 
Tablo1.Türkçeye Yolculuk C1 düzeyi YDTÖ Ders Kitabı 1.Ünite En Sık içerik Kelimeleri

\begin{tabular}{|c|c|c|c|}
\hline & Öne Çıkan Kavram & $f$ & $\mathrm{~T}=1140$ \\
\hline \multicolumn{4}{|l|}{ ira } \\
\hline & Alışveriş & 14 & \\
\hline & Kredi kartı & 12 & \\
\hline & Venezüella & 10 & \\
\hline
\end{tabular}

T: Analiz edilen ünitede toplam kelime sayısı

Türkçeye Yolculuk C1 düzeyi yabanclar dil olarak Türkçe öğretimi ders kitabının 1.ünitesinde ekonomi odaklı içerikler gözlemlenmiştir. Ünite metinleri ekonomi, finans ve tüketim kültürü ile ilgili içeriklere sahiptir. Bu bağlamda ünitede öne çıan alışveriş kelimesinin $\mathrm{f}(14)$, kredi kartı söz grubu f(12), Venezüella kelimesi f(10), frekans değerine sahiptir.

Ünite metinlerinin söyleminde modern insanın tüketim kültürü, kapitalizme yönelik tutumu ve israf edilen kaynaklar üzerinden yoğun bir eleştiri vardır. Bu kapsamda metin yazarları, kredi kartının getirdiği ekonomik gerçeklik ve tüketim kültürü üzerinden öğrencileri uyarmış ve öğrencilerde kapitalizme karşı bir tutum oluşturmaya teşvik edici metin söylemi kullanmışlardır. Ayrıca Venezüella'nın ekonomik sıkıntılarından bahsedilmiş, enflasyon durumu, ekonominin petrol endeksli olması, insanların yaşadıkları problemler metin söylemine yansımış; tek tip üretime sahip ülkelerin ekonomik açıdan sıkıntılarla karşılaşabileceği metin söyleminde ima edilmiştir. Genel değerlendirmeler çerçevesinde metin yazarlarının zihninde hâkim iktidar algısının Batı olmadığı gözlemlenirken; Batı medeniyeti ile müsemma olan kapitalizm, tüketim kültürü metin söyleminde örtük olarak eleştirilmiştir. Öğrencileri tüketim kültürü, kapitalizm konusunda bilinçlendirme ve bu kavramların empoze ettiği davranış biçimlerinin yanlışlığına ikna etme amaçlı söylemler geliştirilmiştir. Ünite kapsamında öne çıkan ilk kelimenin "alışveriş" olduğu gözlemlenmiş olup eşdizimlilik temaları aşağıda gösterilmiştir.

Tablo 2.Alışveriş Kelimesinin Eşdizimlilik Temaları

\begin{tabular}{cccc}
\hline Öne Çıkan Kavram & Sıra & Eşdizimlilik temaları & $f$ \\
\hline & 1 & Araç (araba, sepet vb.) & 7 \\
Alışveriş & 2 & Yap & 4 \\
& 3 & - & - \\
\hline
\end{tabular}

Ünite metinleri içinde öne çıkan ilk kelimenin "alışveriş" kelimesi olduğu tespit edilmiştir. "Alışveriş" kelimesi genellikle araba, sepet vb. araçlar ve "yapmak" fiili ile yüksek değerde eşdizimlilik sahiptir. Ünite metinlerinde insanları tüketime yönelten taktiklerden bahsedilip okurların bu taktiklere karşı bilinçlendirmeyi gaye edinen bir söylem tercih edilmiştir. Bu çerçevede metin yazarları kapitalizm ve tüketim kültürüne yönelik eleştirel bir metin söylemi tercih etmişlerdir. Metin söyleminde kapitalizm içinde tüketimin bir zinciri olan süpermarketlerin 
tüketicilere tuzak kuran ve bu yönleri ile hiç de masum olmayan mekânlar olarak tasvir edilmiş; ayrıca okurları, örtük olarak tüketim çılgınlığından, kapitalizmin dişlisi olmaktan korumaya çalışan bir söylem inşa edildiği gözlemlenmiştir. Bu bağlamda kapitalizm ve kapitalizmin tüketim ahlakı dolayısıyla Batının tüketim kültürü eleştirilirken okurun bu yapılara karşı davranış, tutum ve savunma mekanizmaları geliştirmelerini teşvik edici söylemler bulunmaktadır. "Alışveriş" kelimesinin eşdizimlilik temaları ile ilgili verilerden elde edilen cümleler aşağıda gösterilmiştir:

Eşdizimlilik

\section{Temasi}

1. Araç (araba, sepet vb.) Aşırı büyük alışveriş arabaları marketten çıkarabileceğiniz ve bir arabanın içine sığdırabileceğiniz kadar çok ürünü alacak büyüklükte tasarlanmıştır.

2. Yap süpermarketlerdeki her türlü raf düzeni, cüzdanınız hedef alınarak planlanmıştır. Düşük tempolu müzikler ise insanları daha yavaş gezmeye ve daha çok alışveriş yapmaya teşvik eder. Klasik müzikler ise insanları daha pahalı ürünler almaya yönlendirir.

Ünite bünyesinde öne çıkan diğer ifadenin “kredi kartı” söz gurubu olduğu gözlemlenmiş olup eşdizimlilik temaları aşağıda gösterilmiştir.

Tablo 3. Kredi kartı Kelimesinin Eşdizimlilik Temaları

\begin{tabular}{cccc}
\hline Öne Çıkan Kavram & Sıra & Eşdizimlilik temaları & $f$ \\
\hline & 1 & Kullanmak & 5 \\
Kredi Kartı & 2 & İhtiyaç & 4 \\
& 3 & Sayı (birinci, ikinci vb.) & 3 \\
\hline
\end{tabular}

Ünite metinleri içinde tema ile uyumlu olarak ön plana diğer ifadenin "Kredi kartı" söz grubu olduğu tespit edilmiştir. Kredi kartı" söz grubu genellikle ihtiyaç ve sayısal nitelikler bildiren ifadeler ve "kullanmak" fiili ile yüksek değerde eşdizimliliğe sahiptir. Metin yazarlarının kredi kartına odakladıkları metin söyleminde kapitalizm eleştirisi dikkat çekmektedir. Metinlerde, uzmanlar tarafından bir kişinin sadece bir kredi kartına sahip olması gerektiği ifade edilmiş; ayrıca bireylerin gerçekten ikinci bir kredi kartına ihtiyacının olup olmadığını sorgulamaları talep edilmiştir. İkinci bir kredi kartı alan bireylerin içine gireceği borç yükü eleştirel bir çerçevede ele alınmıştır. Bu değerlendirmeler ekseninde metin yazarları modern insanın tüketim ahlakını eleştirirken, kapitalizmle olan ilişkisini de gözden geçirmesi gerektiğini metin söyleminde ima etmişlerdir. "Kredi kartı" söz grubunun eşdizimlilik temaları ile ilgili verilerden elde edilen cümleler aşağıda gösterilmiştir: 


\section{Eşdizimlilik}

\section{Teması}

1. Kullanmak

2.İhtiyaç
3. Sayı(birinci, ikinci vb.)

\section{Verilerden alıntılar}

Uzmanlar, kişilerin kredi kartı kullanımını tek kart ile sinırlandırması gerektiğini vurguluyor. Ama maalesef durum hiç de bu şekilde değil.

Siz de her beş insandan üçü gibi ikinci bir kredi kartına ihtiyaç duyuyorsanız tekrar düşünün derim.

Otuz günlük dönem sonunda gelecek hesap dökümünüze göre ödeyeceğiniz ikinci bir kredi kartı borcuyla baş etmeye hazır mısınız? Ne dersiniz hâlâ yeni bir kredi kartı istiyor musunuz?

Ünite bünyesinde öne çıkan diğer ifadenin "Venezüella" kelimesi olduğu gözlemlenmiş olup eşdizimlilik temaları aşağıda gösterilmiştir.

Tablo 4.Venezüella Kelimesinin Eşdizimlilik Temaları

\begin{tabular}{cccc}
\hline Öne Çıkan Kavram & Sıra & Eşdizimlilik temaları & $f$ \\
\hline \multirow{3}{*}{ Venezüella } & 1 & Ekonomik problemler (açlık, enflasyon, & 7 \\
& 2 & borç vb.) & \\
& 3 & Petrol & 3 \\
& & - & - \\
\hline
\end{tabular}

Ünite metinleri içinde öne çıan diğer kelimenin "Venezüella" olduğu tespit edilmiştir. "Venezüella" kelimesi genellikle ekonomik problemleri içeren ifadeler ve petrol ile yüksek değerde eşdizimliliğe sahiptir. Venezüella'nın ekonomik durumuna odaklanan metin söyleminde ekonomik göstergeler üzerinden geliştirilen eleştirel ifadeler dikkat çekmektedir. İşsizlik, enflasyon, açlık vb. durumlar petrol odaklı ülke ekonomisiyle ilişkilendirilmiş; okurlara da örtük olarak üretime dayalı ekonomi modelini benimsemeyen ülkelerde sosyali ekonomik problemlerin ortaya çıkacağı ima edilmiştir. "Venezüella" kelimesinin eşdizimlilik temaları ile ilgili verilerden elde edilen cümleler aşağıda gösterilmiştir:

Eşdizimlilik

\section{Verilerden alıntılar}

\section{Temasi}

1. Ekonomik problemler Düşen petrol fiyatları nedeniyle ekonomik krize giren (açlık, enflasyon, borç vb.) Venezuela'da halk zor günler geçiriyor. Her beş kişiden birinin işsiz olduğu ülkede, elektrik kesintileri günde 18 saati bulurken çoğu kasabaya su da verilemiyor.

2.Petrol İş yatırım uluslararası piyasalar müdürü, Venezüella'nın ekonomik durumunu değerlendirdi ve şunları söyledi: "Venezüella'da tamamen petrol gelirlerine dayanan bir ekonomik model var. Zamanında gerekli gelir çeşitlendirmesi yapılmadığından bu model artık işlemiyor. 
Çalışmada incelenen bir diğer ünite Türkçeye Yolculuk C1 düzeyi yabancı dil olarak Türkçe öğretimi ders kitabının 2.ünitesidir. Ünitenin öne çıkan kelimeleri ve frekans değerleri tablolarla gösterilmiştir.

Tablo 5.Türkçeye Yolculuk C1 düzeyi YDTÖ Ders Kitabı 2.Ünite En Sık içerik Kelimeleri

\begin{tabular}{llll}
\hline & Öne Çıkan Kavram & $f$ & $\mathrm{~T}=1587$ \\
ıra & Moda & 28 & \\
\hline & Alışveriş & 12 & \\
- & - & \\
\hline
\end{tabular}

T: Analiz edilen ünitede toplam kelime sayısı

Türkçeye Yolculuk C1 düzeyi yabancllar dil olarak Türkçe öğretimi ders kitabının 2.ünitesinde moda odaklı içerikler gözlemlenmiştir. Ünite metinleri moda, giyim tarzları, alışveriş ile ilgili içeriklere sahiptir. Bu bağlamda ünitede öne çıkan moda kelimesi $f(28)$, alışveriş kelimesi $\mathrm{f}(12)$ frekans değerine sahiptir. Metin yazarları, moda ve tüketim ahlakını metin söyleminde birbiriyle ilişkilendirerek ele almış, ihtiyaç çerçevesinde yapılmayan tüketimler metin söylemine eleştirel olarak yansımıştır. Metinlerde ihtiyaç kavramı ve moda algısının kime, neye göre belirlendiği sorgulanarak okurun bilinçlenmesi öncelenmiştir. Bu bağlamda yapılan eleştirilerden hareketle metin yazarlarının zihninde hâkim iktidar algısı olarak Batı'nın yer almadığı söylenebilir. Ünite kapsamında öne çıan ilk kelimenin "moda" olduğu gözlemlenmiş olup eşdizimlilik temaları aşağıda gösterilmiştir.

Tablo 6.Moda Kelimesinin Eşdizimlilik Temaları

\begin{tabular}{cclc}
\hline Öne Çıkan Kavram & Sıra & \multicolumn{1}{c}{ Eşdizimlilik temaları } & $f$ \\
\hline \multirow{3}{*}{ Moda } & 1 & Uyma (sezona uygun elbise alma, yeni & 12 \\
& 2 & $\begin{array}{l}\text { Sezon ürünü alma vb.) } \\
\text { Tüketim (alma, satın alma) }\end{array}$ & 7 \\
& 3 & Etik & 5 \\
\hline
\end{tabular}

Ünite metinleri içinde öne çıkan ilk kelimenin "moda" olduğu tespit edilmiştir. "Moda" kelimesi genellikle yeni ürünler alıp modaya uyma, satın alma, tüketim gibi ifadelerle yüksek değerde eşdizimliliğe sahiptir. Ünite bünyesinde yer alan metinlerin söyleminde moda ve tüketim kavramları birbiriyle ilişkilendirilmiş ve yoğun bir eleştirel söylem kullanılmıştır. Bu kapsamda metin yazarları, moda kavramını tüketimin artması için oluşturulduğunu, insanların giysilerini kendilerini seçmeyip "moda" kavramını yöneten bir aklın seçtiğini ifade ederek tüketim alışkanlıklarının manipüle edildiği ima edilmiştir. Tüketim, tüketim çılgınlığı ve moda ilişkisi popüler kültür ile ilişkilendirilmiş ve metin söylemine de eleştirel olarak yansıtılmıştır.

Çağın en önemli sorunlarından tüketim kültürü, tüketim çılgınlı̆̆ı için moda etiği kavramı metin söylemlerine yansıyan önemli eşdizimlilik temalarından biridir. Diğer eşdizimlilik 
temalarında bariz şekilde hissedilen eleştirel söylemle birlikte bu duruma alternatifler, çözüm önerileri sunulmuştur. Ayrıca moda kavramı; küresel ısınma, kaynak israfı, türlerin yok olması gibi durumların müsebbibi olarak metin söylemine yansımıştır.

Metin yazarları, okurların popüler kültür ve moda algısı ile tüketim refleksi geliştirme davranışını önlemeye yönelik söylemler gelişirmişlerdir. Metin yazarlarının ayrıca kapitalizm ve Batı medeniyeti eleştirisi de modayı yöneten bir akıl ve tüketimi artırıp, kitleleri yönetmeye çalışan çabalar üzerinden eleştirilmiş ve okurlar bu faktörlere karşı bilinçlendirilmeye çalışılmıştır. "Moda" kelimesinin eşdizimlilik temaları ile ilgili verilerden elde edilen cümleler aşağıda gösterilmiştir:

\section{Eşdizimlilik Teması}

1. Uyma (sezona uygun elbise alma, yeni sezon ürünü alma vb.)

2. Tüketim (alma, satın alma)

3. Etik

\section{Verilerden alıntılar}

Modanın tüketime etkisi birçoğumuz gelecekte neyin moda olacağını öğrenerek kendimizi ona göre hazırlamayı çok isteriz. Neden kendimizi ona göre ayarlamak isteriz, neden modanın adını sık sık duyarız, neden gazete ve dergilerin onlarca sayfasını moda haberleri kaplar? Moda olmasaydı daha mı özgür olunurdu, diye düşünüyorum.

\section{Bir kalıbın içerisindeyiz. Biz seçmiyoruz aslında moda seçiyor} giysilerimizi ve mesaj şu aslında "tüketin!", tüketelim diye var moda. Olmasaydı tüketmeyecek miydik? Tabii ki tüketecektik ama belki de bu kadar hızlı olmayacaktı.

Böylece etik moda anlayışı gelişti. Peki, nedir "etik moda"? Etik moda; yerel zanaatları, adil ticareti, çok işlevli tasarım ürünlerini, çevre dostu malzemelerin kullanımını ve geri dönüşümle değer kazandırılan tasarımları yücelten bir yapıdır. Etik tasarım anlayışının gündeme gelmesi tasarımın hangi koşullarda yaratıldı̆̆ı, üretildiği ve tüketildiğinin sorgulanmasıyla ilgilidir.

Ünite bünyesinde öne çıkan diğer ifadenin "alışveriş" kelimesi olduğu gözlemlenmiş olup eşdizimlilik temaları aşağıda gösterilmiştir.

Tablo 7. Alışveriş Kelimesinin Eşdizimlilik Temaları

\begin{tabular}{cccc}
\hline Öne Çıkan Kavram & Sıra & Eşdizimlilik temaları & $f$ \\
\hline & 1 & Yap & 12 \\
Alışveriş & 2 & - & - \\
& 3 & - & - \\
\hline
\end{tabular}

Ünite metinlerinde ön plana çıan diğer kelimenin "alışveriş" kelimesi olduğu tespit edilmiştir. "Alışveriş" kelimesi “yapmak” fiili ile yüksek değerde eşdizimliliğe sahiptir. Metin 
yazarları, alışveriş yapma eylemini metin söylemlerinde hem olumlu hem de olumsuz yönleri ile ele almışlardır. Olumlu açıdan alışveriş yapmanın ömrü uzattığı, zihinsel fonksiyonlar açısından faydalı olduğu ifade edilerek okurlar alışveriş yapmaya teşvik edilmiştir. Olumsuz açıdan ele alınan alışveriş eylemi ise tüketim çılgınlığı, israf ile ilişkilendirilmiş olup yoğun kapitalizm eleştirisi ile metin söylemlerine yansıtılmıştır. "Alışveriş" kelimesinin eşdizimlilik temaları ile ilgili verilerden elde edilen cümleler aşağıda gösterilmiştir:

\section{Eşdizimlilik Teması Verilerden alıntılar}

1. Yap Alışveriş yapmak ömrü uzatıyor Tayvan'da alışveriş ve sağlık üzerine yapılan bir araştırmaya göre alışveriş yapan insanlar, yapmayanlara göre daha uzun ömürlü oluyorlar. Alışveriş yaparken seçme, beğenme ve hesap yapma zorunluluğundan dolayı beynimiz de zinde kalıyor.

Tüketim çılgınlığı alışveriş yapmak için her zaman geçerli bir bahane bulabilirsin. "Önemli bir görüşmem var ama giyecek hiçbir şeyim yok.", "İndirim sezonunu kaçırmamalıyım." gibi pek çok neden siralanabilir.

Çalışmada incelenen bir diğer ünite Türkçeye Yolculuk C1 düzeyi yabancı dil olarak Türkçe öğretimi ders kitabının 3.ünitesidir. Ünitenin öne çıkan kelimeleri ve frekans değerleri tablolarla gösterilmiştir.

Tablo 8.Türkçeye Yolculuk C1 düzeyi YDTÖ Ders Kitabı 3.Ünite En Sık içerik Kelimeleri

\begin{tabular}{llll}
\hline & Öne Çıkan Kavram & $f$ & $\mathrm{~T}=1530$ \\
\hline 1ra & & 23 & \\
\hline İletişim & 21 & \\
Bayram & 19 \\
Aile & & \\
\hline
\end{tabular}

T: Analiz edilen ünitede toplam kelime sayısı

Türkçeye Yolculuk C1 düzeyi yabancılar dil olarak Türkçe öğretimi ders kitabının 3.ünitesinde iletişim ve yabancılaşama(iletişimsizlik) ile ilgili içerikler gözlemlenmiştir. Ünite metinleri iletişim engelleri, aile, evlilik Türk toplumu ile ilgili içeriklere sahiptir. Bu bağlamda ünitede öne çıkan iletişim kelimesinin $f(23)$, bayram kelimesi $f(21)$, aile kelimesi $f(19)$, frekans değerine sahiptir.

Ünite içeriğinde Türk toplum yapısı ile İslam'ın bileşkesi olarak bayramlardan, bayram geleneklerinden bahsedilmiş; modernizm ile bayram kültürü, Türk toplumsal yapısındaki değişimler, yabancılaşmalar metin söyleminde konu edinilmiştir. Aile içi iletişim kopuklukları ve teknolojinin getirdiği yalnızlığın sonuçları modernizme bağlanmış, örtük olarak eleştirilmiş, okurların aile içi iletişimlerini sıkı tutmaları metin söyleminde teşvik edilmiştir. Ünite kapsamında 
öne çıkan ilk kelimenin “İletişim” olduğu gözlemlenmiş olup eşdizimlilik temaları aşağıda gösterilmiştir.

\section{Tablo 9.İletişim Kelimesinin Eşdizimlilik Temaları}

\begin{tabular}{cccc}
\hline Öne Çıkan Kavram & Sıra & Eşdizimlilik temaları & $f$ \\
\hline \multirow{3}{*}{ İletişim } & 1 & Kur & 8 \\
& 2 & Aile & 7 \\
& 3 & Çocuk & 6 \\
\hline
\end{tabular}

Ünite metinlerinde öne çıkan ilk kelimenin "iletişim" olduğu tespit edilmiştir. "İletişim" kelimesi "kurmak" fiili , "aile” , "çocuk" kelimeleri ile yüksek değerde eşdizimliliğe sahiptir. Aile içi iletişim problemlerine odaklanan metin yazarları güncel olarak karşılaşılan iletişim problemlerinin toplumda bağların çözülmesinde, aileden başlayıp toplumu yönlendiren değerlerin aşınmasında temel faktör olarak değerlendirmiş ve bu durumu metin söyleminde örtük olarak ifade etmiştir. Ayrıca çalışan anne, baba modelinden hareketle metin söyleminde çocuklarını teknolojinin kucağına itildiği ve bu sürecin çocuğu yalnızlaştırdığı, içine kapanık bir birey haline getirdiği, toplumdan ve toplumsal değerlerden çocuğu soyutladığ ifade edilmiştir. Bu kapsamda teknoloji ve yoğun iş hayatı iletişim sorunlarının, toplumsal yapının bozulmasının sebebi olarak okurlara aktarılmış; dolayısıyla modernizmin aile ve toplum hayatı için tehdit olduğu okurlara örtük olarak ifade edilmiş; metin söylemi, okurun yoğun çalışma hayatı, teknoloji yabancılaşma ve aile içi iletişimsizlik durumlarından kaçınması için yapılandırılmış olup okurun davranış ve tutumlarını şekillendirmeye yönelik olduğu tespit edilmiştir. "İletişim" kelimesinin eşdizimlilik temaları ile ilgili verilerden elde edilen cümleler aşağıda gösterilmiştir:

\section{Eşdizimlilik Teması}

1. Kur

2. Aile

3. Çocuk

\section{Verilerden alıntılar}

İletişim kurma şeklini veya kuramamayı bebek yaştan itibaren aile öğretmiştir. Çocuklar da bu davranışın dönütünü büyüdükçe aileye vermektedir.

Günümüzde çok sık rastlanan bir örnek; anne babanın yoğun iş hayatı veya stresli dönemlerinden dolayı, başta çocuğun bilgisayarla vakit geçirmesi ebeveyn tarafından bir avantaj olarak görülür. Ancak uzun vadede aile, bilgisayar bağımlısı, içine kapanık bir çocuk edinmiş olur. Olması gereken aile içi iletişimin yerini bilgisayar, zararlı alışkanlıkları olan bir arkadaş, öfke veya uyuşturucu alabilmektedir.

Onları dinlerken içinde bulundukları duygusal durumu anlayarak, empati kurarak dinlemek için çaba harcamalıyız.

Dinlenmediğini, anlaşılmadığını düşünen çocuklar iletişim kurmak yerine kaçmayı tercih eder.

Ünite kapsamında öne çıkan diğer kelimenin "bayram” olduğu gözlemlenmiş olup eşdizimlilik temaları aşağıda gösterilmiştir. 
Tablo 10.Bayram Kelimesinin Eşdizimlilik Temaları

\begin{tabular}{cccc}
\hline Öne Çıkan Kavram & Sıra & Eşdizimlilik temaları & $f$ \\
\hline \multirow{3}{*}{ Bayram } & 1 & $\begin{array}{c}\text { Modernizm etkisi (teknoloji, değerlerin } \\
\text { değişmesi, kültürün değişmesi vb.) }\end{array}$ & 15 \\
& 2 & Eski & 6 \\
& 3 & - & - \\
\hline
\end{tabular}

Ünite metinleri içinde öne çıkan diğer kelimenin "bayram" olduğu tespit edilmiştir. "bayram" kelimesi topluma, değerlere modernizmin etkilerini aktaran ifadeler ve eski kelimesi ile yüksek değerde eşdizimliliğe sahiptir. Ünite bünyesinde yer alan metinlerde Türk toplum yapısı ve İslam kültürü ile olan bileşkesi değerlendirilirken bayram günlerine odaklanılmıştır.

Metin söyleminde değiş̧en ve dönüşen dünyanın sonucu olarak ortaya çıkan teknolojinin bayram kültürünü ve toplumsal değerleri doğrudan etkilediği ifade edilmiş, aile büyüklerinin bugünlerde teknoloji kavramına ve içeriğine yönelik tepkili olduğu okura aktarılmıştır. Eskiden bayram kavramının köklü geleneklerle büyük bir heyecanla karşılanırken bugünlerde bu geleneklerin kalmadığı, aile hayatından ticarete kadar teknoloji ve modernizm etkisinde erozyona uğradığ1 metin söylemine yansımıştır. Ayrıca geçmişte küçük şeylerle mutlu olan çocukların şimdilerde teknoloji ve modernizm ürünü oyuncak, eğlence araçları ile mutlu olamadığı ifade edilmiş; örtük olarak teknolojinin insanları mutsuz ettiği metin söyleminde vurgulanmıştır. Metin yazarları Batı'nın bir bakiyesi olarak teknolojiyi, tüketim kültürünü bayram geleneklerinin yozlaşmasında temel faktörler olarak okura göstermiş; metin söyleminde okurları bu kavram ve değer dünyasının etki alanı dışında davranış geliştirmeye örtük olarak teşvik etmiştir. Metin yazarlarının zihninde hâkim iktidar algısı olarak Batı'nın olmadığı gözlemlenirken Batı ve değerlerinin Türk toplumu ve gelenekleri özelinde toplumsal yapı ve değerleri erozyona uğrattığ metin söylemine yansımaktadır. "Bayram" kelimesinin eşdizimlilik temaları ile ilgili verilerden elde edilen cümleler aşağıda gösterilmiştir:

Eşdizimlilik Teması

1. Modernizm etkisi (teknoloji, değerlerin değişmesi, kültürün değişmesi vb.)
2. Eski

\section{Verilerden alıntılar}

Aile büyüklerinin özellikle bayram günlerinde, teknolojiye karşı büyük bir düşmanlığı beliriveriyor. Özellikle bu günlerde, bir telefon görmeye dâhi tahammül edemiyorlar. İlerleyen teknoloji ve değişen toplum yapısıyla geleneksel bayram kültürü de farklı bir boyut kazanmış durumda. Eskiden bayramdı, şimdi sadece tatil; belki de bu yüzden doğuyor bu fark. Siz de ah çekip eski geleneksel bayramları özleyenlerdenseniz, nerede o eski bayramlar dedirtecek detaylar sizin de yüzünüzü gülümsetmeye yetecek.

Eskiden bayram telaşı olurdu bayram gelmeden hazırlıklar başlar, arife günü bayram gibi karşılanırdı. Günler öncesinden temizlik yapılır, tatlılar hazırlanırdı. Şimdilerde bayramlar, 
sıradan bir gün bekler gibi karşılanıyor. Herkes evinde misafir beklerdi şimdilerde firsat bulan tatile kaçıyorken eski bayramlarda herkes evde misafir beklerdi. Bayramda ekmek çıkmaz; fırınlar çalışmazdı. Tek bir bayram gazetesi çıktığından gazeteciler de bayram tatili yapardı.

Çocuklar için mutlu olmak daha kolaydı eskiden çocuklar için "mutlu olmak" kavramı çok daha büyük anlam taşıyordu; şimdilerde hiçbir şey onları mutlu edemiyor. Oysa eskiden onlar için en büyük mutluluk konsol oyunları, bilgisayarlar, akıllı telefonlar değil; mahalleye gelen salıncaklara binmekti.

Ünite kapsamında öne çıkan diğer kelimenin “aile” olduğu gözlemlenmiş olup eşdizimlilik temaları aşağıda gösterilmiştir.

Tablo 11.Aile Kelimesinin Eşdizimlilik Temaları

\begin{tabular}{cccr}
\hline Öne Çıkan Kavram & Sıra & Eşdizimlilik temaları & $f$ \\
\hline & 1 & Çocuk & 9 \\
\multirow{2}{*}{ Aile } & 2 & İletişim & 7 \\
& 3 & Çok & 3 \\
\hline
\end{tabular}

Ünite metinleri içinde ön plana diğer kelimenin "aile" olduğu tespit edilmiştir. "Aile" kelimesi "çocuk", "iletişim" ve "çok" kelimeleri ile yüksek değerde eşdizimliliğe sahiptir. Ünite metinlerinde aile kurumunun sahip olduğu değerlerin zaman içinde bozulması, teknoloji etkisiyle oluşan iletişim engelleri gibi konular öne çıkmaktadır. Bu kapsamda ön plana çıkan "iletişim”, "bayram" kelimelerinin söylem analizi ile "aile" kelimesinin söylem analizi benzerlik göstermektedir. "Aile" kelimesinin eşdizimlilik temaları ile ilgili verilerden elde edilen cümleler aşağıda gösterilmiştir:

\section{Eşdizimlilik Teması Verilerden alıntılar}

1. Çocuk İleriki dönemlerle bununla bir sorun olarak yüzleşir çünkü çocuk aile ile iletişim kurmaktan kaçarak tepki verir. Tabii ki iletişim tek taraflı olmaz. Çocuğumuzu dinlemeyi de bilmeliyiz. Çoğu ebeveyn istediği cevapları almaya odaklanarak çocuklarının ne hissettiklerini ne anlatmaya çalıştıklarını fark etmezler. Onları dinlerken içinde bulundukları duygusal durumu anlayarak, empati kurarak dinlemek için çaba harcamalıyız.

2. İletişim Çocuk, bunu ifade edemese bile hissi yaşar ve tanır. Bu arada ebeveyn iletişim kurduğunu düşünerek kendini kandırır. İleriki dönemlerle bununla bir sorun olarak yüzleşir çünkü çocuk aile ile iletişim kurmaktan kaçarak tepki verir. Tabii ki iletişim tek taraflı olmaz. Çocuğumuzu dinlemeyi de bilmeliyiz. 
3. Çok

Günümüzde pek çok aile, çocukları ergen yaşa geldiklerinde aralarında bir iletişim eksikliği olduğunu fark ederler. Ancak çoğu aile bunun çocuktan ya da diş faktörlerden kaynaklandığını düşünerek çözümü yanlış yerde arar.

Çalışmada incelenen bir diğer ünite Türkçeye Yolculuk C1 düzeyi yabancı dil olarak Türkçe öğretimi ders kitabının 5.ünitesidir. Ünitenin öne çıkan kelimeleri ve frekans değerleri tablolarla gösterilmiştir.

Tablo 12. Türkçeye Yolculuk C1 düzeyi YDTÖ Ders Kitabı 5.Ünite En Sık içerik Kelimeleri

\begin{tabular}{llll}
\hline & Öne Çıkan Kavram & $f$ & $\mathrm{~T}=1718$ \\
ıra & & & \\
\hline \multicolumn{2}{c}{ Anne } & 44 & \\
Çocuk & 40 & \\
Mektup & 36 & \\
\hline
\end{tabular}

T: Analiz edilen ünitede toplam kelime sayısı

Türkçeye Yolculuk C1 düzeyi yabancılar dil olarak Türkçe öğretimi ders kitabının 5.ünitesinde aile içi iletişim, çocuklara yeterli zaman ayrılmaması ile ilgili içerikler gözlemlenmiştir. Bu bağlamda ünitede öne çıkan anne kelimesinin $\mathrm{f}(44)$, çocuk kelimesi $\mathrm{f}(40)$, mektup kelimesi f(36), frekans değerine sahiptir.

Ünite metinlerinde temel olarak anne ve çocuk ilişkisi ile ilgili içerikler metin söyleminde gözlemlenmiştir. İçinde bulunduğumuz çağda gelişen ve değişen dünya modernleşme, kapitalist dünya düzeni etkisi ile okura sunulmuş; bu kapsamda iş hayatına katılan annelerin çocuklarına yeteri kadar ilgi gösteremediği ve bu durumun çocuklar üzerindeki fiziksel ve ruhsal etkileri eleştirel bir dil ile değerlendirilmiştir. Metin yazarları, kapitalizm, konformizm, etkisi ve daha fazla kazanma maksadıyla çalışma hayatına katılan annelerin çocuklarını ihmal ettiğini ima edip örtük olarak eleştirmiş; bayan okurların çalışma davranış ve tutumları metin söylemiyle manipüle edilmeye çalışılmıştır. Metin yazarlarının çalışan bayanlara yönelik bu tutumu cinsiyetçi olarak değerlendirilebilir. Ayrıca okurların da çalışma hayatına katılırken önceliklerini belirleme esnasında maddi kaygıları ötelemeleri için ikna edici, mukayeseli bir dil metin söyleminde dikkat çekmektedir. Ünite kapsamında öne çıkan ilk kelimenin "anne" olduğu gözlemlenmiş olup eşdizimlilik temaları aşağıda gösterilmiştir.

Tablo 13. Anne Kelimesinin Eşdizimlilik Temaları

\begin{tabular}{cccc}
\hline Öne Çıkan Kavram & Sıra & Eşdizimlilik temaları & $f$ \\
\hline & 1 & Çocuk & 18 \\
Anne & 2 & Çalışmak (bir yerde çalışan, işe giden, & 13 \\
& & para kazanan vb.) & \\
& 3 & İlgi (çocukla ilgilenme, zaman geçirme) & 10 \\
\hline
\end{tabular}


Ünite metinleri içinde öne çıkan ilk kelimenin "anne" olduğu tespit edilmiştir. "Anne" kelimesi çocuk, çalışmak, çocuklara ilgi gösterme ilgili ifadelerle yüksek değerde eşdizimliliğe sahiptir. Metin yazarları değişen ve gelişen dünyanın kapitalizm etkisi ile anne çocuk ilişkisinde oluşturduğu erozyona dikkat çekmektedir.

Genel değerlendirme ile metin söyleminde çalışma hayatına dâhil olan annelerin kreşlere ve bakıcılara bıraktıkları çocukların fiziksel ve ruhsal ihtiyaçlarını karşılayamadıkları ifade edilip bu tavır örtük olarak eleştirilmiştir. Bu durum artan ihtiyaçlar ve değişen şartlara bağlanmış arka planda kapitalizmin olduğu işaret edilmiştir. Bayan okurların çalışma tercihleri metin söylemiyle manipüle edilmeye çalışılmıştır. Ayrıca metin yazarlarının bu eleştiriler çerçevesinde zihinlerindeki hâkim iktidar algısı olarak Batı'nın olmadığı söylenebilir. "Anne" kelimesinin eşdizimlilik temaları ile ilgili verilerden elde edilen cümleler aşağıda gösterilmiştir:

\section{Eşdizimlilik Teması Verilerden alıntılar}

\section{1. Çocuk}

2. Çalışmak (bir yerde çalışan, işe giden, para kazanan vb.)

3. İlgi (çocukla ilgilenme, zaman geçirme)
Çalışan bir annenin çocuğu olmak çocuğun psikolojini olumsuz etkileyebilir

Annem, "bak, biz babanla işe gideceğiz." der. iş... Bilmem ki ben iş nedir? Ben yastığı bilirim, yorganı bilirim. Oh ne tatlı olur o zaman uyumak... Annem de işe gitmezse geçinemezmişiz. Sonra ev sahibi bizi kolumuzdan tutar atarmış. O ev bizim ki orada benim yatağım var, yorganım var, yastığım var. Ev sahibi kim? Hayat pahalı! O hani saçı kabarık hayat teyze mi?..

Üşüdün mü yavrucuğum?" üşümüyorum. Uykum var...

Bağırmak istiyorum ama bağıramıyorum ki... Bir bağırsam, uykum vaaar!” "yoruldun gel kucağıma." oh... Yatak annem, yastik annem, yorgan annem...

Ünite kapsamında öne çıkan diğer kelimenin "çocuk" olduğu gözlemlenmiş olup eşdizimlilik temaları aşağıda gösterilmiştir.

Tablo 14. Çocuk Kelimesinin Eşdizimlilik Temaları

\begin{tabular}{|c|c|c|c|}
\hline Öne Çıkan Kavram & Sira & Eşdizimlilik temaları & f \\
\hline & 1 & Anne & 2 \\
\hline \multirow[t]{4}{*}{ Çocuk } & & & 3 \\
\hline & 2 & Gelişim (gelişime etki eden faktörler) & 1 \\
\hline & & & 5 \\
\hline & 3 & - & - \\
\hline
\end{tabular}

Ünite metinleri içinde öne çıkan diğer kelimenin "çocuk" olduğu tespit edilmiştir. "Çocuk" kelimesi anne ve çocuğun fiziksel ve ruhsal gelişimine etki eden durumlarla ilgili ifadelerle yüksek değerde eşdizimliliğe sahiptir. Metin söylemlerinde çalışma hayatına dâhil olan annelerin çocuklarının yaşadıkları problemler öne çıkmaktadır. Bakıcıya ya da başka birine bırakılan çocuğun sabah erken kaldırılması, bırakıldı ̆̆ı kreş ya da diğer yerlerde ilgi ve merhametten uzak kalması gibi durumlara ayrıntılı şekilde yer verilmiştir. Bu bağlamda metin yazarları çocukların 
ruhsal ve fiziksel gelişimi için anne ilgisinin önemli olduğunu metin söylemlerine yansıtmış; çalışma hayatına dâhil olup işten geldikten sonra çocukları ile yeteri kadar ilgilenmeyen anneler ise metin söyleminde örtük olarak eleştirilmiştir. Genel olarak içinde bulunduğumuz zaman dilimi, kapitalizm ve artan ihtiyaçlar ekseninde çalışma hayatına dâhil olmanın çocuğun ihmali anlamına geldiği metin söyleminde örtük olarak ifade edildiği gözlemlenmiş; bayan okurların çocuklarıyla doğrudan ilgilenmelerine yönelik metin söylemi manipüle edilmiştir. "Çocuk" kelimesinin eşdizimlilik temaları ile ilgili verilerden elde edilen cümleler aşağıda gösterilmiştir:

\section{Eşdizimlilik Teması}

1. Anne

2. Gelişim (gelişime etki eden faktörler)

\section{Verilerden alıntılar}

Çalışan bir annenin çocuğ $u$ olmak çocuğun psikolojini olumsuz etkileyebilir mi? uzman Pedagog Zehra Yılmaz: çocuğun doğumundan itibaren çalışmayı bırakan anneler ve bir süre sonra işine tekrar dönen annelerin çocukları arasında psikolojik açıdan farklılık olabilir de olmayabilir de.

Hiçbir şey vermez ki anneannem... "koltuğun üstüne çıkma!" der. "pencereden bakma!" der. "balkona adımını atma!" der. En sonunda da, "akşamüzeri annen seni almaya gelsin, yaptıklarını bir bir söyleyeceğim." der.

Çalışsın ya da çalışmasın agresif, sürekli yorgun, bezgin, mutsuz bir anne tabii ki çocuğu olumsuz yönde etkileyecektir. Bu nedenle, annenin, çocuğuyla birlikte geçirdiği dakikalara, işindeki, evindeki sorunları ve kişisel problemleri taşımaması gerekir. Çocŭ̆a yüz ifadesi, hareketler ve sesinin tonuna kadar, sevecen, anlayışlı, sabırlı bir anne tavrı ile yaklaşmalıdır.

Ünite kapsamında öne çıkan diğer kelimenin "mektup" olduğu gözlemlenmiş olup eşdizimlilik temaları aşağıda gösterilmiştir.

Tablo 15. Mektup Kelimesinin Eşdizimlilik Temaları

\begin{tabular}{cccc}
\hline Öne Çıkan Kavram & Sıra & Eşdizimlilik temaları & $f$ \\
\hline \multirow{3}{*}{ Mektup } & 1 & Tür (iş, resmi, özel mektup vb.) & 23 \\
& 2 & İçerik (İçerik özellikleri) & 13 \\
& & - & - \\
\hline
\end{tabular}

Ünite metinleri içinde ön plana diğer kelimenin "Mektup" olduğu tespit edilmiştir. "Mektup" kelimesi mektup türleri ve içerik özellikleriyle ilgili ifadelerle yüksek değerde eşdizimliliğe sahiptir. "Mektup" kelimesinin eşdizimlilik temaları ile ilgili verilerden elde edilen cümleler aşağıda gösterilmiştir:

\section{Eşdizimlilik Teması}

1. Tür (iş, resmi, özel mektup vb.)

2. İçerik (İçerik özellikleri)

\section{Verilerden alıntılar}

Özel, edebî, resmî ve iş ile açık mektuplar olmak üzere dört grupta siniflanmaktadir.

Özel mektuplar akraba ve dost gibi yakın çevredeki insanlara yazılan mektup çeşididir. Bu tür mektuplarda doğal ve samimi 
anlatım vardır. Edebî mektuplar edebî mektuplar; yazarları, içerikleri ve ifade şekilleri ile özel mektuplar içinde ayrı yer tutar ve ayrı şekilde ele alınırlar. Edebî mektuplarda, mektubun yazıldığı dönemin edebiyat ve düşünce olayları yer alır. Yazar, karşısındakine öğ̈̈t verir, yol gösterir.

\section{SONUÇ}

Yabancı dil eğitimi içinde bulunduğumuz zaman dilimi özelinde öğretme ve öğrenme süreçlerinin çok ötesinde anlamlar taşımaktadır. Bu anlam ve değerler dünyası birleşerek öğrenilen hedef dilin kültürü, o dili ana dili olarak konuşan kitlenin toplumsal refleksleri öğrenme materyalleri içine dâhil edilmektedir. Bu çalışmada da Türkçeye Yolcuk C1 düzeyi ders kitabında ünitelerde öne çıkan içerik kelimeleri bilgisayar yazılımları ve eleştirel söylem analizi yöntemi ile incelenmiştir.

Araştırmada ilk olarak Türkçeye Yolcuk YDTÖ ders kitabı ekonomi, finans ve tüketim kültürü ile ilgili içeriklere sahiptir. Ünite metinlerinin söyleminde modern insanın tüketim kültürü, kapitalizme yönelik tutumu ve israf edilen kaynaklar üzerinden yoğun bir eleştiri vardır. $\mathrm{Bu}$ kapsamda metin yazarları, kredi kartının getirdiği ekonomik gerçeklik ve tüketim kültürü üzerinden öğrencileri uyarmış ve öğrencilerde kapitalizme karşı bir tutum oluşturmaya teşvik edici metin söylemi kullanmışlardır. Metin yazarlarının kredi kartına odakladıkları metinlerde kapitalizm eleştirisi dikkat çekmektedir. Okurların kredi kartı kullanma davranışı metin söyleminde manipüle edilmeye çalışılmıştır. Metin yazarları, moda ve tüketim ahlakını metin söyleminde birbiriyle ilişkilendirerek ele almış, ihtiyaç çerçevesinde yapılmayan tüketimler metin söylemine eleştirel olarak yansımıştır. Örtük olarak kapitalizm eleştirisinin yapıldı̆̆ı metinlerde ihtiyaç kavramı ve moda algısının kime, neye göre belirlendiği sorgulanarak metin okurunun davranış ve tutumları metin söylemiyle şekillendirilmeye çalışılmıştır. Diğger bir ünite içeriğinde ise Türk toplum yapısı ve İslam kültürü ile olan bileşkesi değerlendirilirken bayram günlerine odaklanılmıştır. Metin söyleminde değişen ve dönüşen dünyanın sonucu olarak ortaya çıan teknoloji ve modernizm bileşkesinin bayram kültürünü ve toplumsal değerleri doğrudan etkilediği ifade edilmiştir. Ayrıca metin söylemiyle okur davranışları teknolojinin bir çıktısı olarak yabancılaşma kavramından arındrılmaya çalışılmıştır.

Türkçeye Yolculuk YDTÖ ders kitabında anne ve çocuk ilişkisi ile ilgili içerikler metin söyleminde gözlemlenmiştir. İçinde bulunduğumuz çağda gelişen ve değişen dünya modernleşme, kapitalist dünya düzeni etkisi ile okura sunulmuş; bu kapsamda iş hayatına katılan annelerin çocuklarına yeteri kadar ilgi gösteremediği ve bu durumun çocuklar üzerindeki fiziksel ve ruhsal etkileri eleştirel bir dil ile değerlendirilmiştir. Metin yazarları, kapitalizm, konformizm, etkisi ve daha fazla kazanma maksadıyla çalışma hayatına katılan annelerin çocuklarını ihmal ettiğini ima edip örtük olarak eleştirirken okurun tavır ve tutumu da manipüle edilmeye çalışılmıştır. Ayrıca ters açıdan bu durum değerlendirildiğinde metin yazarlarının kadınlara çalışma hayatı ile ilgili cinsiyetçi bir tavırla yaklaştıkları görülmektedir. 
Apple \& King'in (1977) göre okul bilgisi genellikle ideolojik bir amaca hizmet eder. Eleştirel bir açıdan bakıldığında, bu çalışmanın veri seti olarak kullanılan metinlerin dilinin, belirli temaların öğrencilerin zihinsel modelleri (Van Dijk, 2001) ve dünya görüşleri üzerinde etkili olabilecek örtük veya açık sınıflandırmalar taşıdığı sonucuna varılabilir. Hedge (2000:83), örtük müfredatı_"öğretmenin öğrettiği şeylerin dışında gizli yoldan devam eden öğrenme olarak tanımlar. Örtük müfredat; öğrencilerin öğrenme konusundaki algılarının şekillendirilmesini, süreç içerisindeki rollerini, çalıştıkları konunun niteliğini, öğretmenlerini vb. ve bunlara yönelik tutumlarını kapsar. Wallace (1998) da müfredat ve hazırlanan ders materyallerinin kültürel ve ideolojik varsayımlar içerdiğini belirtir. Bu bağlamda Türkçenin yabancı dil olarak öğretimi çok değişkenli bir süreci ihtiva ettiği, diğer yabancı diller gibi sadece öğretim sürecinden ibaret olmadığ1 derin bir örtük müfredat içeriğine sahip olduğu görülmektedir. Müfredat kavramı bu eksende değerlendirildiğinde ilgili eğitim kurumlarının bağlı olduğu kurum, kuruluşların ideoloji ve dünya görüşleri etrafında şekillendirilmekte ve belirli bir amaca hizmet etmektedir. İfade edilen işleyişin en önemli materyali konumunda bulunan ders kitapları yazarların ve kitapları düzenleyen uzmanların fikir, ideoloji, dünya görüşü ekseninde şekillenmektedir. Dil öğrenen bireyler de belirtilen ideoloji, fikir, dünya görüşleri ekseninde örtük olarak şekillendirilmektedir.

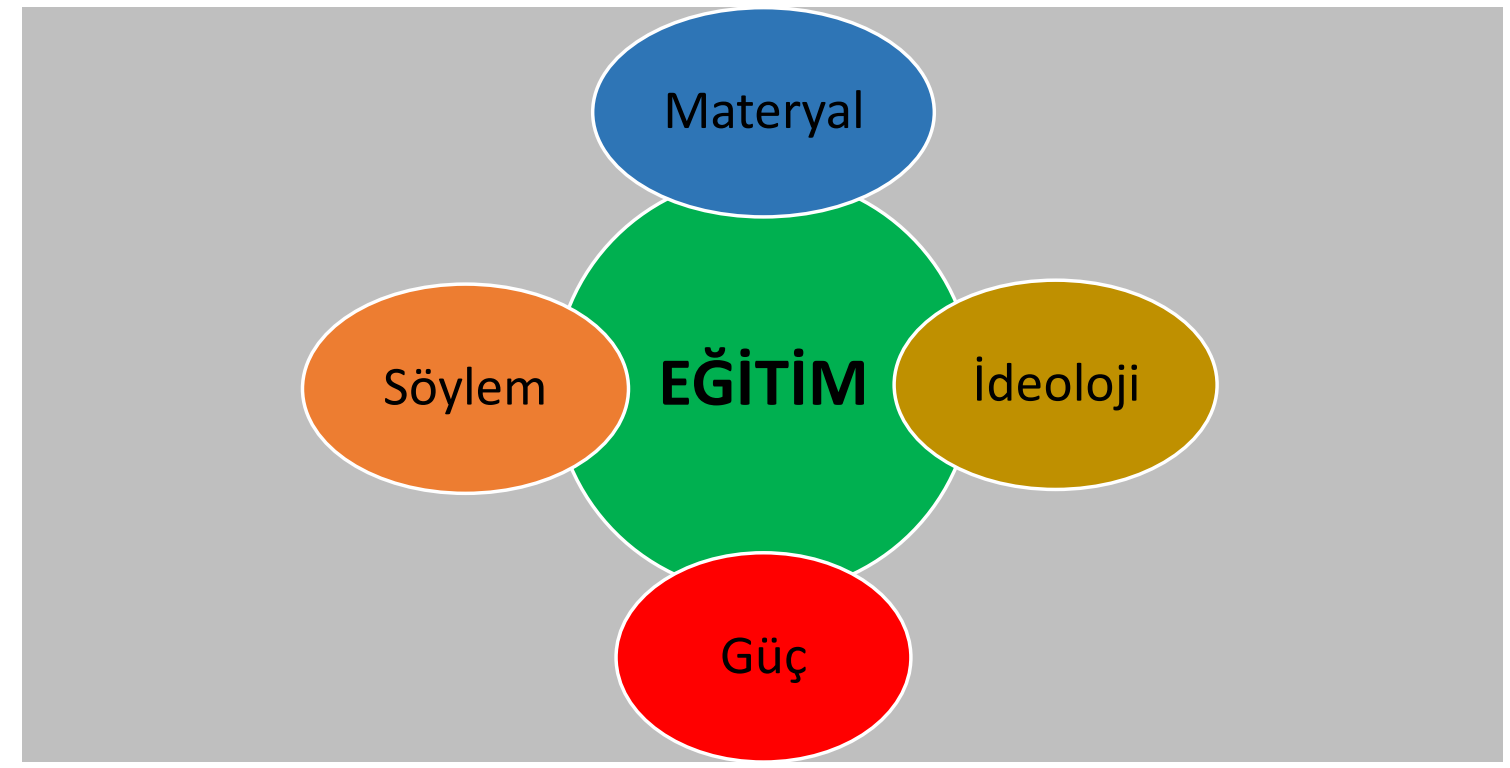

Şekil 3. Eğitim, Söylem, İdeoloji, Güç, Materyal İlişkisi

Nye’a (2005) göre "popüler kültür" önemli bir yumuşak güç kaynağıdır ancak tek biçimli bir kaynak değildir. Bundan dolayıdır ki, bir toplumun belli kesimleri üzerinde olumlu bir tepkiye neden olabilirken, aynı toplumun başka bir kesiminde olumsuz tepkilere neden olabilmektedir. Nye'ın(2005) ifade ettiği üzere eğitim ve kültür faaliyetleri devlet mekanizmalarının kitleleri tanzim etmede kullandıkları en büyük araç olarak bilinmektedir. Bu bağlamda Maarif Vakfínın Asya, Afrika ve diğer kıtalardaki eğitim faaliyetleri Türkiye'nin «yumuşak güç» çıktısı olarak değerlendirilmektedir. Türkçeye Yolculuk YDTÖ ders kitabının Asya ve Afrika coğrafyasında Maarif Vakfı Okulları bünyesinde birçok ülkede kullanıldığı düşünülürse; Batı medeniyeti, kapitalizm, tüketim kültürü ile ilgili okurlara açık ve örtük mesajlar verildiği; metin söylemi ve dil 
eğitimi aracılığıyla okur davranış ve tutumlarının manipüle edilmeye çalışıldığı, okurların zihin ve dünya görüşlerinin şekillendirilmeye çalışıldı ğı görülmektedir.

Türkçenin yabancı dil olarak öğretiminde kullanılan ders kitaplarının içerikleri ve eleştirel söylem analizi neticesinde ortaya çıkarılan bulgular, örtük müfredat öğeleri öğretim sürecinde Nye'ın (2017: 32) ifade ettiği gibi “yumuşak güç” kavramı çatısı altında harmanlanmış, Türkiye'nin orta vadede konumlanacağı düşünsel ve siyasal çizgi açısından bir temel oluşturduğu düşünülmektedir. Bu temel Türkiye'nin uluslararası alandaki okullarında kullanılan ders kitapları ile bina edilmiş; hitap edilen kitlenin düşünsel ve ideolojik şemaları şekillendirilerek davranış ve tutumlarının manipüle edilmek istendiği tespit edilmiştir.

\section{Öneriler}

- $\quad$ YDTÖ süreci Türkiye'nin uluslararası yüzünün önemli bir parçasıdır. Bu bağlamda Uluslararası standartlar açısından «yumuşak güç» analizi yapılarak örtük müfredatın ve materyallerin planlanmaya tabi tutulması gerekmektedir.

- Uluslararası standartlar açısından “Ders Kitabı Enstitüsü” kurularak YDTÖ ders kitaplarının içerik ve dizaynı, alanında uzman ekiplerle gözden geçirilerek daha başarılı çıktılar elde edilebilir.

- Metin yazarları ya da editöryal ekiplerin belli bir fikir, dünya görüşünü benimsemesi, kısmi olarak bu görüşlerin metinlere yansıması normal olarak değerlendirilebilir. Ancak bu görüşlerin ünite ya da kitap geneline baskın şekilde yansıması sürecin amaç ve araç yapısını birbirine karıştıracağı için düzey iyi ayarlanmalı; bu iletiler örtük ve hedef kitlenin muhakeme sistemini çalıştıracak şekilde sunulmalıdır.

- $\quad$ Öğretim elemanlarına eleştirel okuyucular olma anlayışını sağlamak önemlidir ve eleştirel söylem analizi, dil öğretmenlerine, öğrencilere metinlerdeki gizli ideolojileri ortaya çıkarma yeteneği kazandırmak için bir fırsat verebilir. 


\section{KAYNAKÇA}

Apple, Michael. W. \& King, Nancy (1977). What Do Schools Teach? Curriculum Inquiry, 6(4), 341358.

Arkonaç, Sibel A. (2012). Söylem Çalışmaları. Ankara: Nobel Akademik Yayıncılık

Banguoğlu, Tahsin (2015). Türkçenin Grameri. 10. Baskı. TDK Yayınları, (528).

Barın, Erol (1992). Yabancılara Türkçenin Öğretiminde Bir Metod Denemesi. Yayımlanmamış Yüksek Lisans Tezi. Ankara: Gazi Üniversitesi,

Baş, Türker, Akturan, Ulun. (2008). Nitel Araştırma Yöntemleri. Ankara: Seçkin Yayınları.

Çelik, Hilal, Ekşi, Halil (2008). Söylem Analizi. Marmara Üniversitesi Atatürk Eğitim Fakültesi Eğitim Bilimleri Dergisi, (27)27, 99-117.

Durmuş, Mustafa (2013). İkinci/Yabancı Dil Öğretiminde Sadeleştirilmiş Metin Sorunları Üzerine. Bilig, 65, 135-150.

Erdem, İlhan (2009). Yabancılara Türkçe Öğretimiyle İlgili Bir Kaynakça Denemesi [A bibliography essay on the teaching Turkish to the foreigners]. Turkish Studies: International Periodical for the Languages, Literature and History of Turkish or Turkic, 4 (3), 888-937.

Fairclough, Norman (1992). Discourse and Social Change. London: Polity.

Fairclough, Norman (1995) Media Discourse, London: Edward Arnold

Fairclough, Norman, Wodak, Ruth (1997). Critical Discourse Analysis. Discourse studies: A multidisciplinary introduction, 2, 258-284.

Fairclough, Norman (2001). ) Language and Power (2nd edition), London: Longman.

Foucault, Michel (1972). Discipline and Punish. New York: Routledge

Foucault, Michel (2003). Society Must Be Defended. New York: Picador

Gee, James P.(2005). An Introduction to Discourse Analysis: Theory And Method (2nded.). New York: Routledge.

Güllüoğlu, Özlem (2012). “Söylen(Mey)Enin“e Analizi: Bellona Markasına Yönelik Tüketici Algısı Üzerine Bir Söylem Çözümlemesi. Ö. Güllüoğlu (Ed.), İletişim bilimlerinde araştırma yöntemleri: Yazılı metin çözümleme (s. 225-276). Ankara: Ütopya Yayınları

Günay, Doğan (2018). Söylem Çözümlemesi. İstanbul: Papatya.

HOLSTI, Kalevi J. (1964). "The Concept Of Power In The Study Of International Relations," Background, 7/4: 179-194.

Kalın, İbrahim (2012). Türk Dış Politikası Ve Kamu Diplomasisi. Kamu Diplomasisi, 44-56.

Kocaman, Ahmet (2009). Söylem Üzerine. Ankara. ODTÜ Yayıncılık

Korkmaz, Zeynep (1992). Gramer Terimleri Sözlüğü. Ankara: Türk Dil Kurumu Yayınları.

Kress, Gunter. Hodge, Robert. (1979). Language As İdeology. London: Routledge and Kegan Paul.

Morgenthau, Hans J. (1985). Politics Among Nations, rev. Kenneth W. Thompson.

Nixon, Anne, Power, Charmaine (2007). Towards A Framework For Establishing Rigour İn A Discourse Analysis of Midwifery Professionalisation. Nursing Inquiry, 14(1), 71-79.

Nye, Joseph, (2005). Soft Power and Higher Education. Forum for the Future of Higher Education, s.11. 
Nye, Joseph, (2008). Public Diplomacy and Soft Power. The Annals of the American Academy of Political and Social Science, 616(1), 94-109.

Nye, Joseph (2017). Yumuşak Güç (Çev. R. İnan Aydın). Ankara: BB101 Yayınları.

Parker, Ian (1992). Discourse Dynamics: Critical Analysis for Social and Individual Psychology.

London, Routledge

Punch, K. F. (2014). Sosyal Araştırmalara Giriş: Nicel ve Nitel Yaklaşımlar. D. Bayrak, H. B. Arslan ve Z. Akyüz (Çev.), Ankara: Siyasal Kitapevi.

Sözen, Edibe (1999). Söylem. İstanbul: Paradigma Yayınları.

Özdemir, Emin (1983). Ana Dili Öğretimi. Türk Dili (Dil Öğretim Özel Sayısı). Ankara: Türk Dil Kurumu

Türk Dil Kurumu Yayınları (2017) Türkçe Sözlük, (Ankara: TDK Yayınları)

Van Dijk, Teun. A. (1988). Semantics of a Press Panic: The TamilInvasion'. European journal of communication, 3(2), 167-187.

Van Dijk, Teun A. (2000). Ideology and discourse. www.discourses.org 02.12.2019

Van Dijk, Teun A. (2011). Discourse, Knowledge, Power and Politics: Towards Critical Epistemic Discourse Analysis. C. Hart (Ed.), Critical discourse studies in context and cognition (pp. 2764). Amsterdam: John Benjamins Publishing Company.

Wallace, Catherine (1998). Critical Language Awareness İn The Foreign Language Classroom. Unpublished PhD dissertation. London: University of London.

Wodak, Ruth (1995). Critical Linguistics And Critical Discourse Analysis. Discursive pragmatics, 5070.

Wodak, Ruth (1997). Critical Discourse Analysis And The Study Of Doctor-Patient Interaction. In Gunnarsson et al (1997), 173-200.

Yıldırım, Ali, Şimşek, Hasan. (2008). Sosyal Bilimlerde Nitel Araştırma Yöntemleri (6. Baskı). Ankara: Seçkin Yayıncılık. 
TÜRK BILİMKURGU

EDEBIYATI

VE ARKETIPLER

DR. VELİ UĞUR

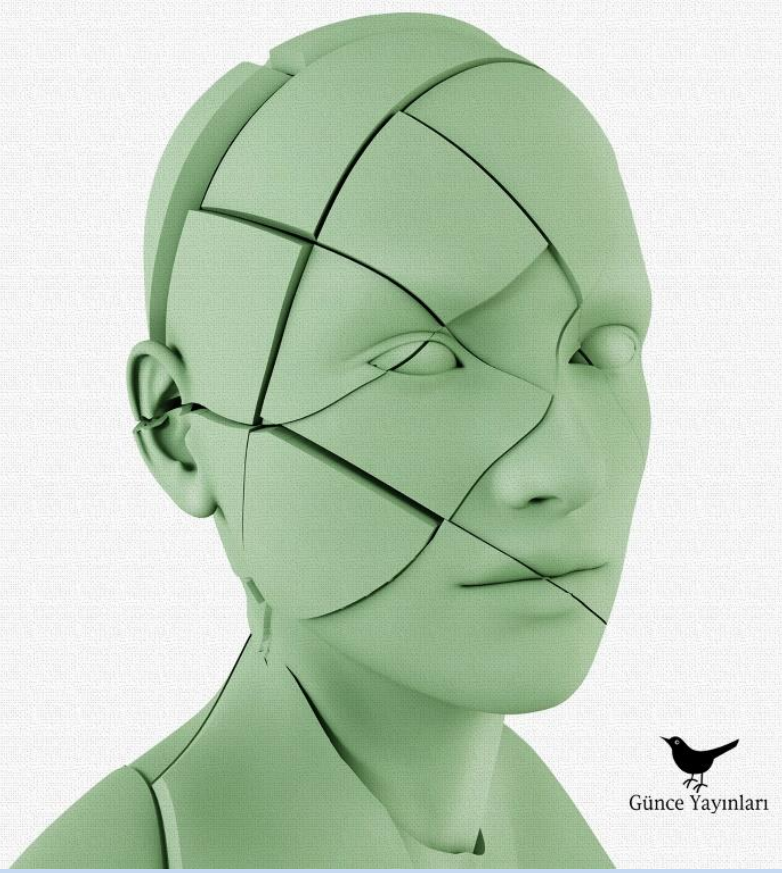

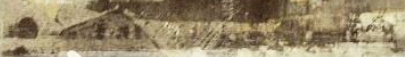

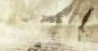

Jktdl| Џill|

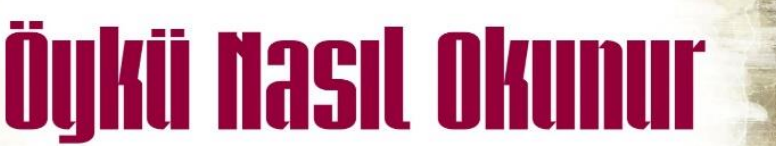

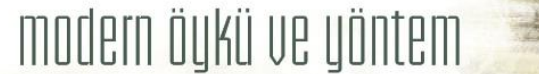

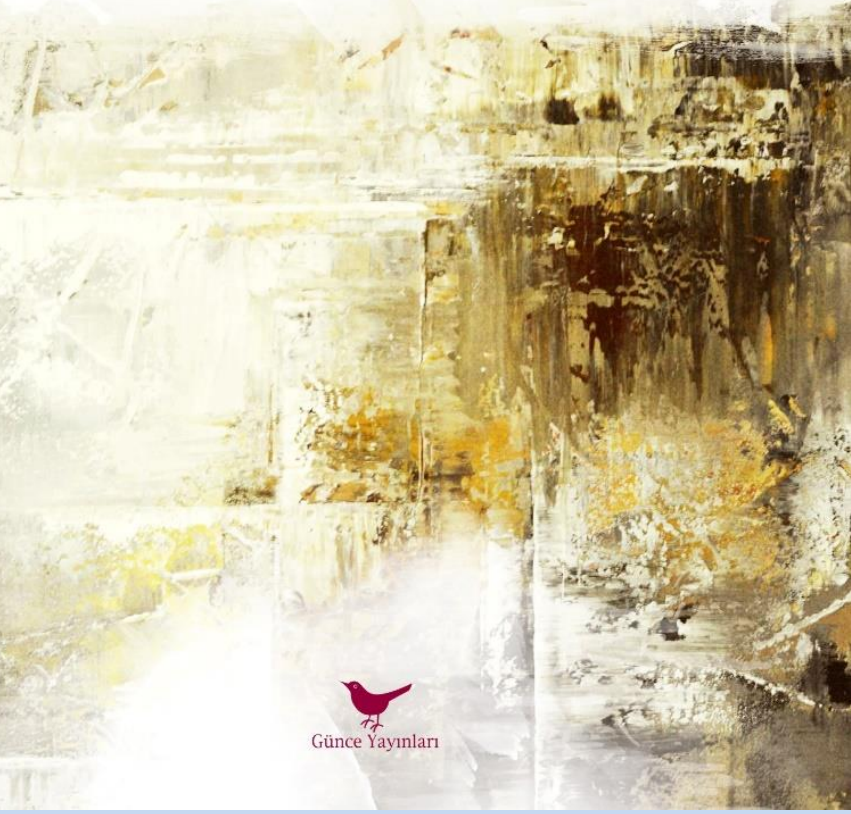

\section{Yazma Sanatı}

Edebivatutn Ebemklusăgu|

Halit Zijya Hilkâyecilliğinde Renklerin Dili

\section{MAKSUT Yit̆̈itBAŞ}

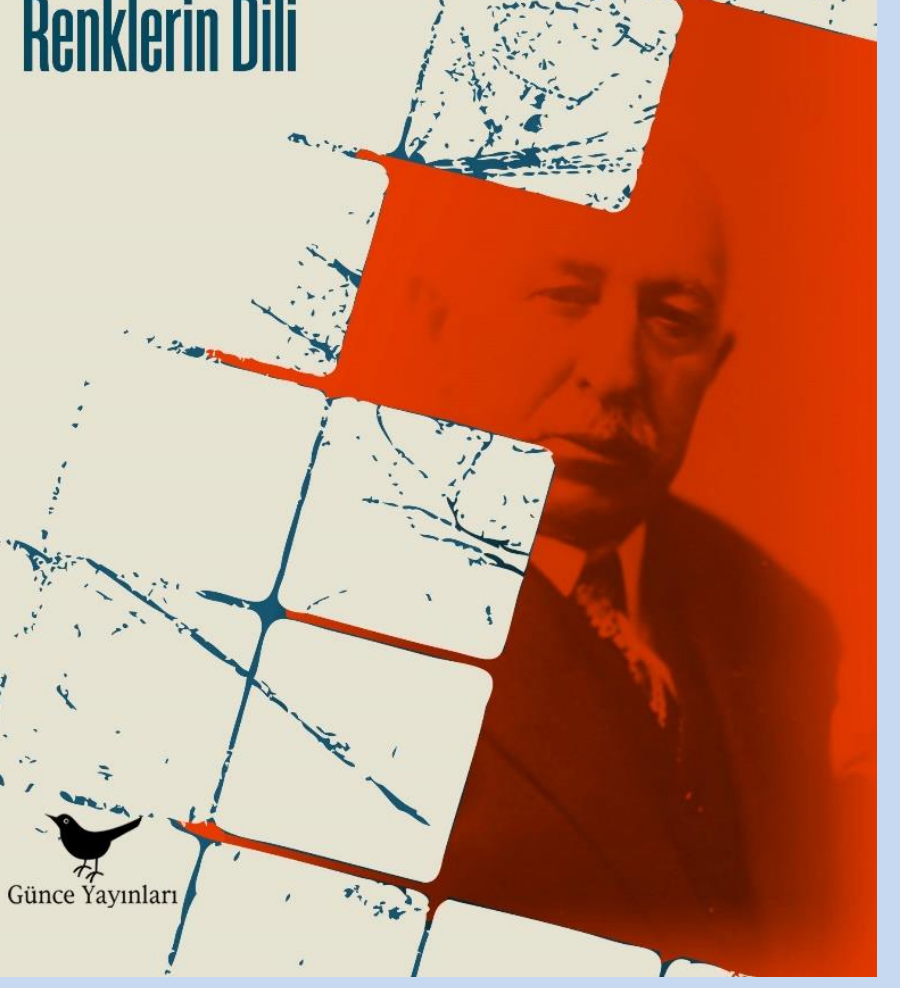

Türkçe Doğru ve Etkili Yazma Teknikleri

Prof. Dr. Önder Göçgün 